\title{
THALES DE AZEVEDO: DESAPARECE O ÚLTIMO DOS PIONEIROS DOS ANTROPÓLOGOS BRASILEIROS DE FORMAÇÃO MÉDICA*
}

\author{
THALES DE AZEVEDO: LAST OF THE \\ PIONEERS OF BRAZILIAN PHYSICIANS-TURNED- \\ ANTHROPOLOGIST PASSES AWAY
}

Não é fácil para mim falar da obra do dr. Thales - uma vida longa, rica de experiências, pontuada por interesses múltiplos, traduzidos numa produção intensa. Inúmeros são meus receios - desinformação, equívocos de interpretação, omissões involuntárias -, todos eles convergindo para um só, o de não fazer jus à incumbência. No entanto, me é igualmente difícil recusar a tarefa, tendo tido o privilégio de acompanhá-lo de perto, enquanto aluna e auxiliar, ou à distância, no exercício do mesmo mister.

Com o passamento do dr. Thales Olympio Goes de Azevedo no dia 5 de agosto de 1995, às vésperas de completar 91 anos, desaparece o último representante dos antropólogos brasileiros de formação médica, uma tradição iniciada no século XIX e que tantos nomes expressivos nos legou: Nina Rodrigues, Arthur Ramos, J. B. de Lacerda, Froes da Fonseca, Bastos d'Ávila, Roquette-Pinto, René Ribeiro, Waldemar Valente, José Loureiro Fernandes, Oswaldo R. Cabral e muitos outros, cujas atividades, em diferentes instituições e regiões do país, foram fundamentais para a implantação e o desenvolvimento da antropologia entre nós.

Uma consulta, ainda que superficial, às suas publicações indica claramente que a expressiva presença de médicos nos primórdios da antropologia brasileira tem a ver com o interesse suscitado entre eles pela nossa diversidade física e cultural, oriunda da presença de diferentes contingentes étnicos em nossa formação, notadamente o negro e o indígena.

Muitos profissionais desenvolveram seus trabalhos no âmbito mais restrito da dimensão biológica, mais preocupados com índices e medidas que dissessem das nossas diferenças. Outros, no entanto, nunca perderam de vista o binômio biológicocultural, ainda que divergissem teoricamente quanto à relação entre esses termos.

$\mathrm{O}$ dr. Thales figura, sem sombra de dúvida, entre aqueles para quem a problemática de corte marcadamente biológico serviu apenas como ponto de partida para o alargamento dos seus interesses.

* Entrevista a Marcos Chor Maio, pesquisador da Casa de Oswaldo Cruz (40 Nicholas Brown Yard, Providence, Rhode Island, 02904 USA marcos_maio@brown.edu). Texto introdutório de Josildeth Gomes Consorte, professora de antropologia da Pontifícia Universidade Católica de São Paulo (PUC-SP). 
Formado em 1927, seus trabalhos científicos, até o final dos anos 30, foram quase todos voltados para assuntos de interesse exclusivamente médico, embora dois deles parecessem prenunciar o antropólogo em que se tornaria mais tarde: uma conferência inédita intitulada 'A medicina entre os selvagens do Brasil', pronunciada naquele ano em Salvador, e um artigo intitulado 'Raças humanas superiores e raças inferiores', publicado em Mundo Médico, no Rio de Janeiro, e no jornal $A$ Tarde, em Salvador, em 1931, "contestando um médico do Rio de Janeiro que admitia aquelas distinções" (Thales de Azevedo, Dados de uma assinatura, p. 53). Seu interesse pela medicina social, todavia, não tardará a surgir, despertado através do contato com Josué de Castro, num curso de extensão sobre alimentação e nutrição que fez na Universidade do Brasil, em 1940, reorientando seus trabalhos na direção dos aspectos sociais da saúde e da medicina que passam, assim, a dominar a sua produção intelectual, até o final da década.

Uma série de outros eventos incumbir-se-ão de tornar os anos 40 decisivos para a sua redefinição profissional, ou seja, para o abandono da medicina pelas ciências sociais.

Atendendo ao convite do prof. Isaías Alves, feito no ano anterior; inicia em 1943 sua atividade docente à frente da primeira cadeira de antropologia e etnografia, na recém-criada Faculdade de Filosofia da Universidade da Bahia. É nesse ano, também, que assume a direção da Escola de Serviço Social e a disciplina de pesquisa social do currículo daquele curso. E, como se não bastasse, tem o prazer de ver editado o seu primeiro livro, intitulado Gaúchos, fruto de sua primeira viagem ao Rio Grande do Sul, terra à qual se ligara pelo casamento, mas que já fazia parte do seu acervo afetivo através de sua avó materna, "cabocla sergipana sempre saudosa dos anos vividos nos pampas ao tempo da guerra do Lopes" (Thales de Azevedo, Gaúchos, agradecimentos).

Como a sublinhar todas essas mudanças, abandona, a partir de então, a clínica médica, atividade à qual se dedicara, durante 15 anos, desde que se formara.

$O$ dr. Thales assume o ensino da antropologia no momento em que a crítica ao evolucionismo de E. B. Tylor e de L. H. Morgan, bem como ao chamado racismo científico, já vai bem avançada. Todo o esforço de Franz Boas e de seus discípulos no sentido de afirmar a não existência de uma relação necessária entre raça e cultura já se encontrava, então, bem consolidado entre os antropólogos, as relações entre os diferentes grupos humanos, qualquer que fosse o contexto em que transcorressem, sendo abordadas, de um modo geral, na perspectiva da dinâmica da cultura ou dos contatos culturais.

Não obstante seu interesse já se achar dirigido para a antropologia social ou cultural, o programa que lhe competia desenvolver no primeiro ano dos cursos de geografia e história e de ciências sociais, à frente da primeira cadeira de antropologia e etnografia, abrangia, principalmente, a antropologia física, disciplina obrigatória na formação dos geógrafos, historiadores e cientistas sociais da época. Porém, uma vez cumprida a programação de antropologia física, ainda profundamente marcada pelo estudo da evolução humana e das diferenças raciais aferidas em termos de índices e de medidas ósseas, o dr. Thales introduzia nos seus cursos temas bem mais fascinantes da sociedade e da cultura com que costumava mobilizar profundamente sua audiência. Assim foi em 1949, quando fui sua aluna e, certamente, terá sido nos anos subseqüentes. 
Pontual e assíduo como poucos, imprimia às suas aulas, dadas sempre de pé, um tom de diálogo, uma absoluta novidade para todos nós. Pródigo em referências às fontes de que se utilizava, recorria amplamente às suas notas, ao longo de suas exposições, procurando nos manter informados dos trabalhos em curso aqui ou lá fora. Alguns dos nomes que tive o prazer de conhecer, pessoalmente, mais tarde, como Maria Julia Pourchet, por exemplo, também recentemente falecida, me foram apresentados através de textos lidos por sua indicação.

A premiação, naquele ano, do livro Povoamento da cidade do Salvador revelará a extensão do seu envolvimento, já naquela altura, com as questões ligadas à nossa formação étnica. Por este e outros motivos, 1949 será outro ano excepcional em sua vida profissional.

Convidado pelo dr. Anísio Teixeira para dirigir o projeto de Pesquisas Sociais Columbia University - Estado da Bahia, um marco no desenvolvimento das ciências sociais entre nós, ganha o reconhecimento público da envergadura que já atingira como cientista social. Na qualidade de secretário de Educação e Saúde do estado da Bahia, o dr. Anísio pretendia assentar as bases dos seus planos educacionais no conhecimento da realidade sócio-cultural produzido por cientistas sociais. Esse projeto, que seria desenvolvido através de estudos de comunidades, criaria a oportunidade para quatro estudantes americanos do Departamento de Antropologia daquela universidade realizarem a pesquisa de campo necessária à elaboração de suas teses de doutorado, abriria a possibilidade para alguns estudantes brasileiros de graduação viverem suas primeiras experiências como auxiliares de pesquisa e alargaria, enormemente, a vivência do dr. Thales como cientista social, colocando-o em contato direto com um dos centros mais renomados de antropologia nos Estados Unidos e projetando-o internacionalmente.

$\mathrm{Na}$ direção desse projeto, partilhada com os profs. Charles Wagley, da Columbia University, e Luiz Aguiar da Costa Pinto, da Universidade do Brasil, o dr. Thales foi inexcedível no zelo com que montou a infra-estrutura local necessária ao seu desenvolvimento e na assistência diuturna que prestou aos pesquisadores onde quer que ela se fizesse necessária. Foi uma grata e imensa surpresa ser convidada por ele, ainda sua aluna, para auxiliá-lo nas diferentes fases do mesmo, e uma experiência inestimável para minha formação ter participado da sua realização.

Em razão de toda essa efervescência, a Bahia foi incluída no grande projeto da Organização Educacional, Científica e Cultural das Nações Unidas (Unesco) sobre o estudo das relações raciais no Brasil, do qual participaram também Rio, São Paulo e Recife. Pertence a esse momento seu trabalho mais importante sobre relações entre brancos, pretos e mestiços, em Salvador, publicado primeiro em Paris, em 1953, e dois anos mais tarde na Coleção Brasiliana com o título As elites de cor: um estudo de ascensão social. $O$ projeto da Unesco representa uma inflexão nos estudos sobre a questão do negro, até então realizados no Brasil, exceção feita ao trabalho do prof. Donald Pierson, Negroes in Brazil, publicado nos Estados Unidos em 1942 e poucos anos depois traduzido para o português sob o título Brancos e pretos na Babia. Os problemas suscitados pela presença africana em nossa formação, que marcaram a obra de Nina Rodrigues, no final do século XIX, a de Manuel Quirino, antes dos anos 20 , e a de tantos outros ao longo dos anos 30 e 40 , dentre os quais avulta o das religiões afro-brasileiras, cedem lugar, naquele momento, à problemática das relações raciais na perspectiva da integração do negro à sociedade de classes. 
O dr. Thales ilustra, exemplarmente, cada momento, no que concerne à cidade de Salvador. Seus trabalhos ao longo dos anos 50 tratarão de mestiçagem, de estereótipos raciais, de preconceito e da ascensão social da então chamada gente de cor.

$\mathrm{O}$ dr. Thales manter-se-á fiel a alguns temas, revisitando-os ao longo dos anos, e irá introduzindo novos, numa produção incessante. As relações entre pretos, brancos e mestiços, o modo de vida das gentes do Rio Grande do Sul e, posteriormente, diferentes aspectos da conjuntura vivida pelo catolicismo, que a sua fé não impedia de abordar, emergem da sua alentada bibliografia como seus prediletos, a julgar pelo número de títulos que a eles dedicou. A partir dos anos 70 , a temática do namoro parece lhe dar um certo prazer, secundada pela do ciclo de vida, revelando preocupações nunca antes esboçadas, com dimensões rituais da existência.

Em mais de um texto, o dr. Thales refere-se à sua formação em antropologia como a de um autodidata, em constante aprendizado da sua disciplina, e ao seu empenho permanente em atualizar-se, pesquisạr e publicar como um compromisso inerente à sua responsabilidade profissional. Sua preocupação com a pesquisa chegava mesmo a transcender motivações particulares, a ponto de, quando um fenômeno de que tinha notícia não o interessava especialmente, não hesitar em buscar quem dele pudesse cuidar, como aconteceu, por exemplo, com o movimento de Santa Brígida.

Não se ocupando do messianismo, escreveu a Roger Bastide sugerindo-lhe que enviasse alguém à Bahia para estudá-lo, tarefa que recaiu sobre Maria Isaura Pereira Queiroz, a quem fui apresentada na ocasião e cuja amizade muito me honra.

Creio que também fazia parte do manter-se atualizado e participante este amplo relacionar-se com os seus colegas de profissão. Conhecia-os pessoalmente, e se mantinha informado sobre o trabalho de cada um, através de uma troca assíclua de correspondência. Sempre me impressionou muito o vasto conhecimento que possuía, de pessoas e de fontes bibliográficas e documentais, de tal forma que, dificilmente, uma consulta ou um pedido de orientação que lhe fosse dirigido ficavam sem resposta.

Tornou-se, com o tempo, uma referência obrigatória para todos quantos se dirigiam à Bahia para estudos, pesquisas ou simples visita. Aposentando-se da universidade, em 1967, antes da instalação dos programas de pós-graduação, manteve-se tão atuante na vida acadêmica como se ali ainda permanecesse. De 1980 em diante, costumava dizer ter tomado para si um princípio de Oswaldo Cruz: "Não esmorecer para não desmerecer." Ao falecer, organizava uma coletânea de vários autores sobre 'Modos de ser brasileiros'.

Josildeth Gomes Consorte

Para os interessados em mais detalhes, a íntegra do depoimento do prof. Thales de Azevedo pode ser consultada no Acervo de História Oral da Casa de Oswaldo Cruz. A entrevista integra o projeto Raça, Ciência e Pensamento Social no Brasil. Verificar, também, Brandão, Maria de Azevedo. Thales de Azevedo: dados de uma assinalura. Salvador, Associação Brasileira de Antropologia/Universidacle Federal da Bahia, 1993. 


\section{Origens familiares e escolaridade}

Prof. Thales, quais as suas origens familiares? Onde o senhor nasceu?

Sou baiano, nascido, criado e vivido sempre aqui na Bahia. Nunca quis sair daqui e tenho uma família muito grande, oito filhos: quatro rapazes, quatro moças e 31 netos e bisnetos. Sou completamente radicado em Salvador.

Qual é a origem dos seus pais?

Meu pai era farmacêutico. Tinha 13 irmãos, sendo que seis mulheres, todos os seis liberais, nenhum comerciante, nenhum sacerdote, gente assim; e do lado materno a família é menor e mais modesta, também de formação liberal, engenheiros, bacharéis...

\section{Todos de Salvador?}

Do interior da Bahia, mas vivendo aqui em Salvador. Meu avô paterno era de Santo Amaro, José Olympio de Azevedo, e meus avós maternos eram sergipanos e ligados a família da minha senhora, que era aqui de Conceição do Coité.

Qual o nome dos seus pais, por favor?

Meu pai era Ormindo Azevedo, farmacêutico, e minha mãe era Laurinda Goes de Azevedo, a Lola, normalista, ensinou alguma coisa no começo da vida dela, mas depois, com o crescimento da família... teve cinco filhos, abandonou essa atividade. Minha senhora [Mariá] é uma baiana nascida no Rio Grande do Sul, porque o pai dela era médico-militar e serviu no Rio Grande; ela nasceu lá em Alegrete.

Em seu universo familiar há a presença muito forte de médicos, não é?

Ah, é, a família do meu pai tinha muitos médicos, farmacêuticos e alguns bacharéis e a família de mamãe era mais da engenharia... profissionais liberais, nenhum comerciante, nenhum sacerdote...

\section{Como foi sua infância aqui em Salvador?}

Meu pai era um homem simples, modesto e tinha uma farmácia muito boa perto de casa. Era uma das farmácias principais daqui, muito freqüentada por médicos dessa cidade, de maneira que foi nesse ambiente que eu me criei.

O senhor foi alfabetizado em casa ou em um colégio?

Comecei a ser alfabetizado em casa, mas logo fui para o Colégio Padre Antônio Vieira, de jesuítas portugueses. Foi decisiva para mim a formação neste colégio, sobretudo o curso secundário. Toda a minha formação escolar foi feita nesse colégio.

\section{"Comecei a ser alfabetizado em casa, mas logo fui para a Colégio Padre Antônio Vieira, de jesuítas portugueses."}

Que aspectos seriam determinantes nessa formação?

Os cursos eram muito bons, professores com experiência internacional, todos esses chamados escolásticos, jesuítas ainda não ordenados, eram rapazes que tinham estudado na França, na Espanha, que iam colaborar... 
De quais matérias o senhor mais gostava, tinha mais afinidades...

Não me recordo de uma em particular, mas era um curso muito interessante porque geografia incluía cosmografia e línguas, francês e inglês, eram muito bem ensinadas. Nunca necessitei de qualquer outro curso. Dei palestras na França, Inglaterra, Bélgica, Espanha sem nunca necessitar de um curso especial de línguas.

Em casa o senhor tinha uma mãe professora primária; ela era muito presente ou não? Mamãe me ajudava muito; ela estudou álgebra para me ensinar o que nunca tinha estudado; meu pai nunca teve um papel direto nesse particular, até porque ele morreu muito cedo.

\section{Quantos anos o senbor tinha?}

Quando ele morreu, eu não tinha feito 12 anos de idade. Morreu subitamente, deve ter tido um infarto fulminante, de maneira que com esse ramo paterno de doutores, médicos, farmacêuticos, bacharéis eu tinha muito pouca aproximação pessoal; a minha aproximação era maior do lado materno, onde não tinha nenhum intelectual, mas eram pessoas de formação liberal também: engenheiros, uma professora formada em letras em nivel de pós-graduação... Tinha gente com muito gosto pela pintura, pintura de cópia, porém muito bem-feita, ainda hoje nós temos trabalhos, de modo que isso influiu muito em mim. Minha atividade de aquarelista foi inspirada um pouco por isso.

\section{Sua familia era religiosa?}

Quando mamãe enviuvou é que se aproximou muito da religião, das Senhoras de Caridade, das Mães Cristãs, mas antes não era, não tinha ninguém religiosamente acentuado. Essa posição de mamãe e o trabalho no colégio me tornaram católico participante, militante etc. Aí pelos anos 30, 40, o arcebispo me designou presidente do Conselho Arquidiocesano da Ação Católica. Eu trabalhei, me destaquei muito, no sentido da presença; isso me levou a escrever um dos primeiros trabalhos sobre o catolicismo no Brasil, publicado pelo Ministério da Educação, em 1959.

\section{“Quando mamãe enviuvou se aproximou muito da religião... Essa posição de mamãe e o trabalho no colégio me tornaram católico participante, militante."}

Eu queria fazer uma certa cronologia: o senhor entrou no Colégio Padre Antônio Vieira com que idade?

Aos 12 anos. Fiquei até 1919, quando terminei o curso secundário. Foram cinco anos: quatro do curso secundário e um ano do curso primário. Não, eu entrei no segundo ano primário, mas os padres quiseram me transferir pulando sobre o terceiro primário para o primeiro ginasial, e aí meu pai não aceitou isso e exigiu que eu fizesse exame e tal, e passei.

E o senbor fez o preparatório [correspondente ao segundo grau] em dois anos?

Não, o preparatório em quatro anos. 
O senhor teve irmãos? Eles enveredaram por que caminhos?

Tenho um irmão e tive duas irmãs. As duas irmãs estudaram na Escola Normal, e uma delas foi secretária da Secretaria de Agricultura; a outra foi professora-orientadora escolar, e o irmão trabalhou em várias coisas, nunca se diplomou, nunca estudou regularmente.

\section{O senbor se lembra como era a Bahia de sua juventude?}

Salvador devia ser uma quinta parte de hoje; tinha bondes, praticamente não tinha automóveis. Era uma cidade comercial, um posto de certa importância no Brasil e tinha uma Faculdade de Medicina notável. Era uma coisa extraordinária a faculdade, tenho alguma coisa escrita sobre isso. A Faculdade de Medicina era a primeira escola humanística também, com uma biblioteca muito variada; tinha uma Faculdade de Direito também. A de medicina foi inaugurada em 1808, a de direito, em mil oitocentos e noventa e tantos, além das de engenharia e belas-artes.

Quando o senhor freqülentava a farmácia do seu pai, quais eram as doenças e os tipos de remédios que os médicos prescreviam? Como era a situação da saúde?

Havia o impaludismo, que hoje chamam malária, muita tuberculose, aquela forma clínica com emagrecimento, suores noturnos, expectoração com hemoptises etc. Tive um tio, o Ramiro de Azevedo, que foi um dos fundadores da Liga Baiana contra a Tuberculose e morreu tuberculoso: ele e a esposa dele; tive também um tio materno que foi vítima dessa tuberculose.

\section{"Tive um tio, o Ramiro de Azevedo, que foi um dos fundadores da Liga Baiana contra a Tuberculose e morreu tuberculoso: ele e a esposa dele."}

\section{O senhor tem outras lembranças familiares de doenças mortais?}

Não, eu próprio nunca tive. Nunca tive uma infecção microbiana, contagiosa, a não ser o chamado paratifo, em 1922. Naquele tempo, uma doença muito importante era o tifo, febre tífica, ou tifo, ou paratifo, que era uma forma clínica benigna, porém ligada à mesma origem microbiana.

Esse perído em que o senhor estudou no Colégio Padre Antônio Vieira foi quando aconteceu a Primeira Guerra Mundial?

Foi, meu pai tinha comércio com a Alemanha, tanto que ele ganhou um quadro, uma fotografia comprida com a vista do porto de Hamburgo; esse quadro desapareceu. Mamãe depois revelou que ela tirou e escondeu quando a guerra arrebentou; mas a posição dominante na minha família era favorável aos Aliados. Lá em casa conheci a literatura contra os boches, devo ter um livro sobre os bombardeios de Liège e não sei que outras cidades, mas era sobretudo mamãe quem mantinha esse clima.

Na sua infância, lembra de alguma epidemia que tenha marcado o senhor?

Não... depois de formado, fui mandado para o interior, em comissão, para vacinar a população numa cidade. Naquela ocasião, havia uma epidemia de peste bubônica em 
Vitória da Conquista, com 150 casos, setenta óbitos. Essa epidemia nunca foi descrita, mas foi muito importante.

Nunca foi descrita, ninguém escreveu, nem um bistoriador?

Ninguém escreveu, nem crônica... teve muito noticiário nos jornais, fora não.

\section{Lembra em que ano aconteceu?}

Em 1928. Eu tinha me formado em medicina em 1927 e estava à procura de trabalho. Fui pedir ao secretário de Saúde algum trabalho e ele me disse que havia um pedido de alguém que fosse para São Francisco, onde tinha uma epidemia de impaludismo, ou então para Itambé, um município vizinho de Vitória da Conquista, para vacinar a população contra a peste. Aceitei este convite porque eu não podia tomar quinino, tinha intolerância por quinino, não podia ir para uma zona de impaludismo. Fui para Itambé, mas também lá a população não quis se vacinar. Estive lá dois meses, vacinei 28 crianças da escola pública e ninguém mais.

\section{Por que as pessoas não queriam se vacinar? Elas tinham medo da vacina?}

Não sei se tinham medo ou se não acreditavam na vacina, apesar da epidemia em Vitória da Conquista. Estive lá, onde tinha um outro médico, com quem me relacionei muito bem. Eu passava o dia na casa desse médico ouvindo a vitrola dele, ele tinha um disco... não me lembro, ouvi esse disco dezenas de vezes.

\section{E era que tipo de música?}

Música romântica, melódica: Amapola. Esse médico viveu ainda muitos anos e eu encontrei com ele aqui na Bahia há uns dez ou 15 anos.

\section{Qual seria a origem étnica de sua familia?}

Eram todos filhos daqui da Bahia; minha senhora é que é David, mas ela não sabe o que era esse David. Um dos ascendentes dela era de Nantes e está enterrado aqui na Igreja de São Pedro dos Clérigos. Perguntei ao prof. Jean de le Mour quem eram os David de lá, e ele disse: "Olha, podem ter sido árabes ou judeus." Meus tios paternos que estudaram medicina migraram todos para São Paulo, para Minas e um deles foi para o Rio Grande do Sul, mas a nossa vida é aqui na Bahia.

Então a origem é remotamente portuguesa, talvez.

Portuguesa e alguma coisa africana, porque meu avô paterno era um moreno, mulato mesmo, mulato brancóide, por aí. O materno não sei se teve alguma coisa remota de holandês, com nome Goes, não sei se era de origem holandesa.

\section{A opção pela medicina}

Como foi sua decisâo de seguir a carreira médica?

Quando meu pai morreu, eu era afilhado de um senhor, que era chefe de uma grande firma comercial, e ele ofereceu a mamãe um lugar no que chamava a loja dele: um escritório de exportação. Mamãe me conteve até que eu terminasse os preparatórios; só uns dois anos depois fui trabalhar no comércio durante uns três 
anos; foi uma fase também muito boa. Eu tinha cultura geral e a vantagem de ler inglês e francês com facilidade. Quando chegou à Bahia, Frederico Edelweiss era mineralogista, veio do Rio Grande e, não sei por quê, foi para o comércio. Mas esta aproximação com o Frederico foi decisiva para a minha vida; eu me tornei amigo próximo dele, freqüentei a sua casa, onde ele constituiu uma biblioteca excepcional.

Que está hoje em dia na universidade, no Terreiro de Jesus, não é?

É, o Centro de Estudos Baianos, no prédio da velha Faculdade de Medicina. Ele era um homem de muito boa orientação, ajudei-o a abrir pacotes de livros que ele importava da Alemanha, livros ingleses, americanos, muita coisa de literatura. Depois, ele começou a importar material relativo à história do Brasil; isso me sobreveio uma influência muito forte.

\section{Como entrou para a Faculdade de Medicina?}

Aprendi que não tinha futuro no comércio e tinha aquela tradição de uma profissão liberal. Tinha um grande dilema: comunicar a esse padrinho que eu queria estudar medicina. Mas tinha medo de ele se descontentar comigo, mas ele foi muito gentil, atencioso, aprovou, me encorajou, mas nunca me ajudou. Ele era um homem de recursos, nunca me deu nada. Comuniquei a ele e ele aceitou a minha idéia de estudar medicina. Eu me matriculei na faculdade para fazer o exame de admissão, mas como vinha o carnaval, não cuidei, e um dia, quando saía de casa para o comércio, encontrei um colega, que me perguntou se eu tinha feito a prova escrita naquele dia. "Que prova escrita?" "Rapaz, a nossa prova de admissão." E eu fui para a faculdade e lá encontrei um professor, amigo da minha família, que deu um atestado de saúde para eu fazer essa prova no outro dia.

\section{Quem era o professor?}

Alfredo Magalhães, professor de pediatria, tinha um serviço muito bom aqui na Baixa do Sapateiro. Fiz essa prova de admissão atrasado, mas tirei o primeiro lugar, eram uns setenta e tantos candidatos.

Em geral, quais eram os exames exigidos no concurso para a Faculdade de Medicina? História natural sobretudo, botânica, zoologia, português, exame pessoal, com uma comissão de três professores.

O senbor se lembra quem fazia parte da banca?

Um deles foi o Egas Muniz Barreto de Aragão.

O senhor teve aquela experiência no comércio, poderia ter feito direito, que também seria uma profissão liberal. O que pesou foi a tradição familiar?

Tradição familiar e o meio em que eu convivia.

Seria porque a medicina tinha mais status que o direito, ou não?

$\mathrm{Na}$ minha família predominavam a medicina e a farmácia, e isso influiu muito.

A Faculdade de Medicina era um lugar assim de...

Formação liberal muito apurada, a faculdade tinha uma biblioteca voltada para as questôes étnicas e coisas assim. 
No livro As ciências sociais na Bahia, o senhor cita teses e mostra essa confluência da medicina com a sociologia, esse encontro.

'As teses de medicina', um trabalho do prof. Francisco Pinheiro, é modelar e nunca foi publicado, mas é fundamental para conhecer a orientação da faculdade.

As idéias filosóficas?

É, filosóficas. As teses da faculdade, ele com a Dinorah Neves de Castro.

Na Faculdade de Medicina havia orientação humanista. Gostaria que me relatasse um pouco mais sobre essa experiência.

$\mathrm{Na}$ faculdade, o professorado não era rigorosamente científico; eram homens cultos, eruditos, bem-falantes, mas que não tinham a formação sistemática... por exemplo, nós tivemos um grande professor de fisiologia, que dava aulas brilhantes sobre audição, visão, era um experimentalista. E, como ele, havia vários outros. Tinha o movimento mais rigorosamente científico com o Pirajá da Silva, para zoologia. Sobre o prof. Pirajá tem um livro muito bom, de Itasil Benício dos Santos.

Pirajā, se não me engano, tinha laços com a Escola Tropicalista Baiana...

Escola Tropicalista Baiana é uma designação posterior, porque não era sistematicamente uma escola, nem uma corrente de pensamento. [Otto] Vucherer, Silva Lima e Paterson tinham interesse pela cirurgia e esse grupo não era de professores da faculdade.

Muito interessante o senhor traçar esse perfil dos professores da Faculdade de Medicina, porque a impressão que dá é que, se isso fosse dito na segunda metade do século $X I X$, seria a mesma coisa. Eram pessoas eruditas, não experimentalistas, essa era a critica que, por exemplo, Nina Rodrigues fazia à Faculdade de Medicina.

Nina Rodrigues foi um caso completamente fora do habitual, aquele interesse dele sociológico e etnológico... inclusive venceu os preconceitos da época. Montava no seu cavalo para ir até Gantois, vencendo dificuldades de toda ordem.

\section{"Nina Rodrigues foi um caso completamente fora do habitual... inclusive venceu os preconceitos da época."}

Sempre se coloca isso: a falta da experimentação na medicina. O seu relato, agora, demonstra que essa situação permaneceu, mesmo ao longo dos anos 20, quando o senbor fez faculdade.

Eram homens cultos, bem-falantes, inclusive alguns oradores. Eu, por exemplo, tive um professor de fisiologia que dava brilhantíssimas aulas sobre cinema, que terminavam todos os anos em palmas e tudo o mais.

Qual era o nome desse professor erudito de quem o senhor estava falando?

Aristides Novis, um homem culto, brilhante, dava aulas muito bonitas.

A que atribui a manutenção dessa erudição, da cultura bumanista? No Rio de Janeiro, por exemplo, tem todo o trabalho de Oswaldo Cruz, Carlos Chagas, já encontramos uma tradição de pesquisas mais objetivas. 
Aqui era mais literatura, mais erudita no sentido de geral. O clima baiano não era de progresso comercial diversificado. Quando o comércio do açúcar quebrou, a Bahia não soube se orientar no sentido de uma nova atividade produtiva, ficou naquela saudade do engenho, da fazenda, da plantação de cana. Era preciso alguém ter estudado essa coisa da mentalidade baiana.

Quais as matérias com que o senbor tinha mais afinidades, mais gostava, na Faculdade de Medicina?

Não tenho idéia de que matérias eu mais gostava. Eu não sei que palavra dar à medicina baiana do meu tempo... mas não era muito experimental, era muito sentimental.

Quanto à sua tese de doutoramento na área de medicina, como se definiu o tema que resolveu pesquisar?

Fui auxiliar do prof. José Adeodato, ginecologista e obstetra, de maneira que procurei um tema relacionado com essa área. Adeodato era um daqueles médicos antigos muito cultos em línguas, em francês, em latim etc., um escritor. Ele tinha um livro, um estudo sobre a menstruação, e escolhi aquela matéria para a tese de doutoramento.

\section{"Fui auxiliar do prof. José Adeodato, ginecologista e obstetra, de maneira que procurei um tema relacionado com essa área."}

\section{Em que consistia essa tese?}

Era sobre um tumor uterino muito freqüente, um mioma uterino, e aparecia muito na clínica ginecológica da Santa Casa. Operava-se muito, fazia-se a ablação do tumor cirurgicamente.

A Bahia fica conhecida por duas tradiçōes que aparecem fortes nos livros de história da medicina: a chamada Escola Tropicalista Baiana e a tradição de Nina Rodrigues. Na sua época de faculdade, o senbor via realmente a presença de um interesse, uma tradição de estudos na área de antropologia física ou estudos étnicos?

Não propriamente uma coisa que me chamasse a atenção. Eu me interessei por isso quando Isaías [Alves] fundou a Faculdade de Filosofia e, talvez por sugestão de Frederico Edelweiss, me chamou para ensinar antropologia. Na faculdade mesmo, não, porque tinh́a aqueles professores... Com a preparação que eu tinha do curso secundário, tive facilidade de ler a Enciclopédia Britânica e foi por onde entrei na antropologia. Eu conto em algum trabalhinho ou artigo as coisas que eu li naquela ocasião.

\section{E quanto a Estácio de Lima, foi seu professor?}

Em 1927. A medicina legal era dada no quinto ano e ele nos impressionou pela eloqüência, pelo entusiasmo, mas o Estácio, aqui para nós, não era um homem metódico, um homem organizado cientificamente. Ele era um homem sentimental, aproveitava-se muito da sua facilidade de falar disso e daquilo e tal. Apesar de ter estudado alguma coisa na Alemanha, ele não apanhou um método mais objetivo. É uma coisa muito melindrosa falar sobre isso aqui na Bahia. 
Estácio foi uma pessoa muito importante na tradição antropológica?

Antropológica não, sexológica. Sexo foi uma das coisas sobre as quais ele escreveu melhor. Mas o Estácio era muito dispersivo, usava uma linguagem muito chocante; eu me lembro de uma palestra dele na Faculdade de Medicina, no salão nobre, em que ele falava em pentelho e coisas assim, com muitas senhoras presentes. Agora, ele é homem de merecimentos, sem dúvida nenhuma, tem aquele mundo místico dos bandidos e não sei de quê... Estácio foi à África sem um programa científico. Ele voltou de lá e escreveu um livro, Mundo místico dos negros, parece, mas não tem um conteúdo objetivo, de temas que ele tenha procurado estudar. Aliás, lá ele se prestou a assistir uma clitoridectomia: a moça sem anestesia, ele confessa isso no livro dele. Ia haver a cerimônia da excisão clitoridiana e ele foi avisado por um português, pediu autorização, arranjaram um guarda, e ele foi assistir. E tirou as fotografias.

\section{Política e religião}

No início dos anos 20, o senhor já escreve artigos falando sobre questões ideológicas e, se não me engano, tem um artigo sobre socialistas.

Aquilo foi por causa do meu catolicismo, porque o Partido Socialista pareceu muito anticatólico, então em 1925 eu escrevi no Diário da Babia um artigo contra ele.

Então esses artigos ideológicos eram mais reativos a certas posturas em relaçâo à Igreja Católica?

Eram. Porque os jesuítas... é muito curioso esse caso: eles não me incutiram nenhuma intolerância, nenhuma resistência pessoal direta contra fulano ou sicrano, por ter tal ou qual modo de pensar, mas alguma coisa apologética com relação ao catolicismo, de maneira que eu tomava posição nessa base.

Ao mesmo tempo que começa a escrever artigos médicos em revistas especializadas, a partir dos anos 30, o senbor tem uma atividade religiosa e política. Não políticopartidária, mas a da juventude católica. Fale um pouco dessa experiência, por que razão se envolveu na organização da Ação Católica?

Não havia ação católica formal, havia ação católica individual; Ação Católica propriamente foi de 1935, e sobretudo 1945, em diante.

São duas datas, nâo é, por que 1935?

Em 1935, iniciou-se aqui na Bahia alguma coisa da Ação Católica formalmente definida; eu até tenho aqui um livro de atas desse período. Agora, em 1945, a Ação Católica foi propriamente criada.

É interessante verificar a experiência que o senhor teve nos anos 30.

Foi então que começou a pregação comunista e a integralista, e o integralismo teve, aqui na Bahia, uma influência muito grande.

Uma influência grande? Eu gostaria que o senhor falasse um pouco sobre esse período. Toda a rapaziada católica daquela época aderiu ao integralismo. Eu não aderi, me isentei completamente, nunca fui integralista, nunca entrei na sede da Ação Integralista, 
na ladeira de São Bento. Fui até a porta, à procura de Joaquim Araújo Lima e de alguns outros conhecidos, mas nunca entrei, não participei diretamente.

\section{"Eu não aderi, me isentei completamente, nunca fui integralista, nunca entrei na sede da Ação Integralista."}

Por que tantos católicos se envolveram e o senhor nâa? Não é um fenômeno restrito à Babia.

Eu li os artigos de Alceu [Amoroso Lima], que se isentou, embora houvesse um artigo dele em que fazia um elogio a essas coisas de integralismo, mas ele não aderiu propriamente, então eu segui mais essa linha.

O senbor não aderiu, tudo bem, mas por quê? Quais seriam os aspectos doutrinários que...

Nunca quis me comprometer com qualquer movimento que me obrigasse a tomar posições que eu não seguisse.

Conhecia bem o dr. Santos Pereira, médico formado antes do senhor, que era chefe integralista? Se relacionava bem com ele? Ele era muito ligado a Plinio Salgado. Conhecia o Plinio?

Conhecia e não tinha relacionamento muito próximo, tinha algum relacionamento. Meu irmão, Renato Azevedo, ainda hoje no Rio, era muito integralista. Chegou a levar o Plínio à nossa casa, na Santa Clara do Desterro, para um almoço. Na ocasião, Plínio fez uma palestra aqui no Campo da Graça.

Dentro da família só o seu irmão simpatizou com o integralismo?

Tive um tio, da Bahia, João Carvalho Goes, que foi mártir do integralismo. Ele era radioamador, e teve como atribuição se comunicar com os alemães por meio do rádio. Foi muito perseguido; ele morreu anos depois, muito perseguido.

Queria insistir nessa pergunta sobre a questão do integralismo: não haveria o aspecto ligado à visão de que o integralismo cheirava a totalitarismo? Isso não o incomodava? Aquela idéia de o chefe ter uma autoridade direta sobre cada participante me repugnava, eu achava aquilo uma coisa que... até porque havia aqui uns beneditinos alemães, que eram muito contra Hitler, o dom Mauro, que era capelão aqui da Graça. Ele dizia rindo que na Alemanha havia liberdade de pensamento e umas coisas assim, mas fazia aquilo ironicamente.

Estou me lembrando de um personagem que apareceu aqui na nossa conversa e eu gostaria que o senhor abrisse um parêntese: é Isaías Alves.

Isaías foi um homem que se dedicou à psicologia educacional e escreveu muito sobre isso em 1942. Em 1943, ele fundou a Faculdade de Filosofia e aliciou pessoal jovem de alguma condição e professores das faculdades; e eu fui levado nessa corrente.

Quais as figuras políticas que o senhor admirava, tinha respeito... governadores ou lideres governamentais? 
Não tenho a lembrança mais viva, quem eu possa recordar. O Getúlio sempre me chamou atenção pelo personalismo, por aquela tendência ditatorial e também pelo fato de que ele tinha um filho, ao qual deu o nome de Lutero. Achei aquilo significativo do modo dele pensar, porque é um nome pouco comum entre nós, e um nome significativo ao protestantismo. Eu não participava da política na Bahia, aquilo pouco me tocava.

No Rio de Janeiro, a Igreja tinha uma força razoável nos anos 30, com padre Leonel Franca, um grande intelectual, e dom Sebastião Leme. Quem eram os intelectuais católicos na Bahia, nesse periodo?

Aqui havia um padre, João de Barros, homem inteligente, mas muito popular. Havia monsenhor Tapiranga, homem idoso, muito respeitável, piedoso e também muito inteligente, com fama de muito talento, monsenhor Flaviano Ozório Pimentel, que por sinal é tio de João Ubaldo [Ribeiro]. O padre Cabral e os jesuítas, o padre Torrend, um intelectual, mas, ao mesmo tempo, uma pessoa de temperamento muito agradável, que explorava o lado afetivo da vida humana.

Um outro assunto: há marcas históricas, e eu gostaria de saber suas impressões, sua vivência na revolução de 30 aqui na Babia?

A Bahia aderiu com dificuldade à República, à revolução de 30 , foi sempre mais demorada em se pronunciar de um modo mais concreto, objetivo.

E o golpe de 37, o Estado Novo?

Todo movimento mais conservador tinha melhor repercussão na Bahia, sempre mais conservadora.

E a Segunda Guerra Mundial, do que o senbor se lembra?

A Segunda Guerra foi sempre aquela mesma questão da Primeira Guerra, alemães e Aliados. Como lhe contei, lá em casa, não sei se meu pai seria de orientação mais para os alemães, mas tinha interesses comerciais com eles. Mamãe, ao contrário, tanto que ela escondeu uma fotografia de Hamburgo e essas coisas assim.

O senbor era amigo do Eduardo de Moraes? Ele foi da sua turma de 1927?

Foi o paraninfo, posição disputada com Estácio [de Lima], mas ele era mais velho, mais respeitado, mais querido.

O senhor não se ligou à Legião de Médicos para a Vitória, na Segunda Guerra, dirigida por ele?

Não diretamente, sempre me isentei muito, não sei por quê, nunca quis participar muito.

O senhor participou através do catolicismo, não é?

Não formalmente, em movimentos, esses ou aqueles.

\section{O exercicio da medicina}

O senhor faz o doutoramento, e é aí que começa sua experiência profissional: primeiro na clinica e depois no interior, em Castro Alves? 
Eu me diplomei em 27 de dezembro de 1927 e fui pedir algum trabalho ao Barros Barreto, que era secretário de Saúde. Ele me disse que tinha pedidos de médicos para atender a um surto de impaludismo no rio São Francisco e para vacinar a população de Itambé, vizinha de Vitória da Conquista, onde estava havendo aquela epidemia de peste bubônica. Preferi esta última, porque acreditava na vacina e eu não podia tomar quinino.

\section{"Eu me diplomei em 27 de dezembro de 1927 e fui pedir algum trabalho ao Barros Barreto, que era secretário de Saúde."}

Tem um Barros Barreto que é sanitarista no Rio de Janeiro, e trabalha com Carlos Chagas.

É possível que seja parente, mas não é ele. Barros Barreto foi botânico especializado em insetos...

Quando foi pedir a Barros Barreto, qual era a expectativa em termos de trabalho?

Eu não tinha proteção de ninguém para começar uma vida de clínico. Então, só mesmo exercendo uma função oficial.

Quais eram as opções na época?

Clínica ou emprego no Departamento de Saúde.

O senbor saberia o nome daquele dr. Cordeiro que foi chefe da missão contra a peste? Eram cinco médicos: Figueiredo, um preto que saiu de lá escorraçado porque buliu com uma senhora, Durval Silva Lima, e mais dois. Eu tenho um retrato tirado com Durval Silva Lima e Régis Pacheco, que era prefeito de Itambé, foi intendente naquela ocasião. Foi o único médico que não fugiu da epidemia de peste bubônica.

Havia outros médicos na região?

Não, na cidade só tinha esse médico.

E depois dessa experiência de combate à peste bubônica?

Eu voltei para a capital e fiquei sem ocupação, não tinha emprego nenhum, nem tinha clínica, era muito jovem e não tinha maneira...

Como o senhor vivia?

Com mamãe, que era viúva já, e podia ir me mantendo num sobradinho branco que eu tenho ali na Santa Clara do Desterro, em frente ao convento.

O senhor também teve uma clínica em Castro Alves? Em que ano mais ou menos, o senhor tem uma idéia?

Em 1929, o dr. Antônio Leoni, que era clínico em Castro Alves, foi nomeado assistente de Aristides Novis. Ele era casado com uma Novis e me falou na possibilidade de eu ir para lá. Fui lá e ele me apresentou à população, me vendeu o seu consultório, inclusive mostruário, ferramentas cirúrgicas, toda aquela coisa. Foi muito importante, 
quando cheguei a Castro Alves, encontrar na casa do dr. Antônio Leoni uma grande coleção de números do Journal of the American Medical Association. Ele tinha feito uma assinatura, pensando que era em espanhol, e quando viu que era em inglês ele deixou. Recebia e nem abria, e eu li muito ali. Havia, inclusive, uma seção de notícias mandadas do Brasil pelo correspondente da revista no Rio de Janeiro, de modo que aquilo para mim foi do maior interesse.

\title{
"Foi muito importante, quando cheguei a Castro Alves, encontrar na casa do dr. Antônio Leoni uma grande coleção de números do Journal of the American Medical Association"
}

Qual era a sua atividade como médico? Era clínico geral?

Clínica geral, mas também operando. Eu amputei a perna de um paciente com... essa coisa que dá gangrena, diabetes. Fiz pequenas operações, assim.

Era uma cidade pequena? Perto de Salvador?

Era uma cidade pequena, mas há muito calçada, com energia elétrica, água encanada, um lugarzinho... a uns trezentos quilômetros daqui.

Interessante, mais tarde escreveria um artigo sobre a doença de Chagas em Castro Alves, não é?

Porque lá tinha muito barbeiro, as casas eram infestadas desse bicho... Fiquei lá por uns três anos.

Já eram bem aceitas as formulações de Carlos Chagas?

Era bem conhecido o trabalho de Chagas. Ele foi logo muito bem acolhido.

Nesse periodo, que vai dos anos 20 até mil novecentos e quarenta e poucos, fiquei observando que o senbor escreve nas principais revistas médicas. Queria que me falasse um pouco dessa relação: tem o Brasil Médico, a Bahia Médica, a Cultura Médica, a Hora Médica, que é um jornal de grande tradição no Rio de Janeiro, a Revista Médica da Bahia...

A grande tradição era o Brasil Médico, do Azevedo Sodré. Eu mandèi um primeiro artigo, aceitaram, e daí em diante não fizeram restrição. Várias notas que mandei publicaram... Herbert Fortes me convidou para ajudar a traduzir a tese dele do alemão para o português. Creio que um dos primeiros artigos de 1928 ou 1929 do Brasil Médico, sobre hemossedimentação, foi meu. Ele me deu um conjunto daqueles aparelhinhos para medir sedimentação, tubos de sedimentação, e então escrevi um trabalho.

\author{
"Creio que um dos primeiros \\ artigos de 1928 ou 1929 do Brasil Médico, \\ sobre hemossedimentação, foi meu."
}


Em 1928, Azevedo Sodré morreu, por sinal um grande médico e político também. Como era esse contato? Mandava o artigo e eles publicavam, aceitavam, não tinha um contato maior?

Nunca tive dificuldade em publicar. E foi nessa ocasião que Herbert [Parente Fortes] diagnosticou o 'sarcoma' dele, indo ao Convento de São Francisco para o trabalho, com esse médico, Helmut Schmidt, sentiu uma dor muito forte, fez uma radiografia e verificou que tinha um sarcoma e aí foi operado. Mas ele era um homem de coragem extraordinária, de maneira que se adaptou muito bem.

Herbert Fortes tem um trabalho sobre raças, a biografia dele está sendo escrita por Oldegard Franco Vieira. Quando comenta, em sua memória, sobre os grandes amigos que teve na época escolar, um seria Anisio Teixeira e o outro é ele.

Ligado ao movimento da Congregação Mariana Acadêmica e clo Círculo Católico de Estudos da Mocidade Acadêmica, uma associação que se reunia, tinha o Álvaro Sampaio, que freqüentava para ouvir palestras, eu pronunciei uma palestra lá sobre a medicina dos índios que nunca publiquei, deve estar nessa resma de papéis.

O senhor tem um artigo em que critica um médico que defende as desigualdades raciais. Quem é?

Alguém escreveu um artigo admitindo a existência de raças superiores e inferiores e eu escrevi contestando. O Mundo Médico publicou este artigo.

Quais foram suas bases para criticar esse artigo?

Naquele tempo já era freqüentador da biblioteca de Frederico Edelweiss e eu tinha idéias derivadas dessas leituras. Ele já importava livros da Alemanha, livros americanos, livros ingleses e eu o ajudei a abrir muitos pacotes de livros.

O senhor poderia ter recebido livros que confirmassem as idéias raciológicas da época. Os livros eram variados... Little Lord of Fauntleroy [de Frances Hodgson Burnett], eu li duas vezes na biblioteca de Frederico, aliás, um livro encantador. Ele importava, depois começou a se especializar em história do Brasil, mas, a princípio, era literatura em geral e, talvez ainda, alguma coisa da mineralogia que ele cultivava.

Quando consegue um trabalho no IAPM [Instituto de Aposentadoria e Pensões dos Marítimosl, o senhor faz um segundo curso de aperfeiçoamento no Rio de Janeiro, na época da Constituinte de 1933.

Um curso de dermatologia [e sifilografia].

Como o senhor decidia que cursos fazer? Dependia da freqüencia desse tipo de doença aparecer em seu trabalbo?

Procurando alguma coisa em que pudesse trabalhar produtivamente, do ponto de vista pecuniário, pensei em me dedicar à dermatologia. Então fui fazer esse curso na clínica do prof. Eduardo Rabelo, que tinha um filho, o Rabelo Neto, que era um rapaz muito inteligente. Estudava muito lepra, que hoje ninguém fala mais, é hanseníase, e o pessoal não sabe o que é, pensa que é uma coisa diferente. 


\section{"Procurando alguma coisa em que pudesse trabalhar produtivamente, do ponto de vista pecuniário, pensei em me dedicar à dermatologia. Então fui fazer esse curso na clínica do prof. Eduardo Rabelo..."}

Em 1940, o senbor faz um curso com o prof. Josué de Castro?

Bom, aí eu já estava no Departamento de Saúde, como médico, e procurei ser designado para fazer esse curso com Josué. Lá, estive demoradamente com o Josué, me liguei muito proximamente a ele. Fui eu quem fez o discurso de saudação no final do curso, essas coisas assim, e ficamos amigos, conhecidos, até a ocasião em que ele morreu. Eu o visitei em Paris, na rua Lord Byron. A casa dele era muito brasileira, com colunas, plantas brasileiras, coisas assim e tal. Me dei muito com Josué, apesar de que eu não seguia as idéias políticas dele. Josué era muito esquerda, eu não, mas do ponto de vista pessoal fui muito ligado a ele.

Queria que o senhor falasse desse curso com Josué, mas, antes, gostaria de saber como entrou para a Secretaria de Saúde daqui do estado.

Fui pedir um emprego e fui atendido pelo secretário de Educação e Saúde, e ele me designou secretário do Conselho de Assistência Social. Eu trabalhei um período com ele nesse conselho, mas depois passei já com Isaías [Alves] secretário, para o Departamento de Saúde e foi também quando obtive o lugar no IAPM.

Foi tudo ao mesmo tempo, quer dizer, o senhor foi da Secretaria de Saúde e do IAPM de 1934 a 1938? O senbor ia lá e pedia um emprego, trazia uma carta... como era essa bistória?

Aquele professor que era secretário [de educação e saúde, Agripino Barbosa], antes de Barros Barreto, eu o conhecia da faculdade, de modo que fui pessoalmente pedir a ele algum trabalho, um emprego mesmo. Então ele me designou secretário de Assistência Social e daí eu consegui, quando Isaías entrou, passar para o Departamento de Saúde.

Ainda sobre sua vida profissional nos anos 30: o senhor participou como médico do IAPM, que foi o primeiro instituto a ser criado, não é?

Fui o primeiro médico do Instituto dos Marítimos na Bahia, tanto que se deu uma coisa muito curiosa: apareceu um marítimo com herpes e eu disse: "Isto é zona!" Ele disse: "Alto lá, zona não. Eu sou um homem casado, não faço zona" [zona é a denominação corrente para zoster, um tipo de herpes caracterizada por erupção de grupos de vesículas de um lado do corpo, seguindo o curso de um nervo].

\section{"...apareceu um maritimo com herpes e eu disse: "Isto é zona!" Ele disse: "Alto lá, zona não. Eu sou um homem casado, não faço zona."}

Dava status participar de um instituto naquela época?

Eu andava procurando emprego, e pedi a Juracy [Magalhães], o governador. Ele me entregou a Manoel Novaes, deputado durante trinta anos. Novaes era médico conhecido 
meu, era um pouco mais jovem do que eu. Novaes mexeu, virou, e depois de uns dias me disse: "Olha, eu lhe arranjei um lugar de médico do Instituto dos Marítimos." Foi o primeiro emprego formal que eu tive.

Em 1931 o senbor foi para o Rio Janeiro fazer um curso de especialização com Clementino Fraga, não é?

Na clínica de Clementino. Foi quando eu comprei a minha primeira máquina de escrever usada, velha, ali nos Arcos da Lapa.

E como foi essa experiência?

Quando fomos eu já era casado, não tinha filhos, mas havia uma pensão na rua do Matoso, muito modesta, muito barata por sinal, eu fui daqui levando uma quantia de setecentos mil-réis porque, na volta, já queria ter com que subsistir e não gastei no Rio de Janeiro esse dinheiro. No Rio de Janeiro, havia um primo de Mariá [senhora de Thales de Azevedo], médico do Exército, que me ajudou muito, me levou ao Hospital do Exército, essas coisas.

Queria saber como foi esse encontro e, depois, o casamento com d. Mariá.

Ela morava numa rua perpendicular à minha, e eu passava ali freqüentemente, daí surgiu o namoro e o casamento. O casamento foi em 1931, e eu tinha me formado em 1927.

Uma nota de Gilberto Freyre foi transcrita na abertura de seu livro Gaúchos. Ele afirma que seu primeiro trabalho na ärea das ciências sociais, sobre o rancho dos gaúchos $e$ uruguaios, é de 1941, já que antes estaria voltado para a medicina social.

Sim, porque eu escrevi algumas coisas nesse particular.

Ele escreve: "Tendo estado no Rio Grande do Sul, o sr. Thales de Azevedo se enamorou de tal modo da paisagem cultural daquela região brasileira, que o estudo sociológico das coisas rio-grandenses-do-sul, hoje, se não são sua especialidade, que continua sendo a medicina social, têm o seu maior entusiasmo."

Eu escrevi algumas coisas nesse particular; aquela bibliografia minha que lá está deu indicação desse tipo de coisas.

Fica a impressão de que, nos anos 20, 30, seus artigos são voltados para a medicina clinica, mas, depois, no caso, Gilberto Freyre menciona essa parte de medicina social. Não seria a associação entre medicina e alimentação a preocupação com esse tipo de...

Sim, meu contato com uma população nova, como era a de Castro Alves, quando recebia em meu consultório nunca menos de vinte pessoas mandadas pelo prefeito diariamente, das quais eu não cobrava coisa nenhuma, me abriu uma certa perspectiva para os problemas sociais.

Disse que recebia vinte pacientes por dia, em média. Como era essa relação médicopaciente, o modo de os médicos tratarem dos pacientes?

Tinha um problema interessante: havia um médico velho, tradicional, mas muito apegado a velhos princípios. Ele não acreditava muito em micróbio, no bacilo de 
Koch, por exemplo; então não tinha apreço por assepsia. Fervia a seringa e depois, com o lenço tirado do bolso, enxugava e botava na caixinha para dar injeção. Certa ocasião, veio uma menina com uma inflamação no braço, perguntei o que era aquilo: "Toda vez que o dr. Jambeiro me dá injeção fica assim." Tudo isso me chamou a atenção, esse desapreço dele pela falta de assepsia, ele não acreditava muito em micróbio. Rafael Jambeiro era compadre de toda a população de Castro Alves. Aquilo tudo afetava nossas relações, que, aliás, eu mantinha muito boas; almocei muitas vezes na casa dele etc.

Como se diferenciava dele no tratamento dos seus pacientes, já que ele tinha principios tradicionais, não acreditava em micróbios?

Ele não tinha um consultório instalado, atendia na casa dos clientes e na casa dele, de uma maneira muito informal, mas era muito popular por causa da influência que exercia no município em geral, e até em municípios distantes.

O senhor conheceu Roquette-Pinto? Froes da Fonseca?

Não, acompanhei muito o movimento da criação da Rádio, mas nunca estive com ele. Froes da Fonseca conheci muito, porque era professor de grande prestígio aqui na Bahia. Escreveu uma tese de 17 páginas e com essa tese fez o concurso para professor de anatomia, aqui na Bahia. Depois continuei me relacionando com ele durante muito tempo.

\section{A conversão para a antropologia social}

Depois ele tornou-se professor de antropologia.

Vou lhe falar: tenho um artigo intitulado 'Biológico e cultural em antropologia', em que dou um pouco de história, da idéia da antropologia no Brasil, explicando por que os médicos foram os preferidos para primeiros professores de antropologia. A idéia que se fazia é que antropologia era uma anatomia, uma antropologia física, e talvez eu próprio fosse levado para a antropologia por isso.

Era essa a razão para os médicos serem preferidos?

Preferidos como os primeiros professores de antropologia: os médicos e os padres no Rio Grande do Sul. Aqui na Bahia, o frei Fidelis Ott, que ainda está vivo, Carlos Borromeus Ott, doutor em teologia.

Gostaria de entender melhor a trajetória de Froes da Fonseca: em que época ele foi professor na Faculdade de Medicina da Bahia?

Anos 20, foi por aí.

Froes da Fonseca participa do Congresso de Eugenia de 1929, com um artigo a favor da mestiçagem, dizendo que a mestiçagem não tem nenhum problema... vários autores trabalhavam nesse sentido, o da degeneração através da mestiçagem.

Nenhum problema de achar que a mestiçagem predispunha para a tuberculose e etc. 'Pethion de Villar', o Egas Muniz Barreto de Aragão [poeta baiano] escreveu nessa ocasião sobre a sífilis e a mestiçagem. 
O senhor encontrou nos americanos que vieram estudar antropologia na Babia algo referente à degeneração, alguma coisa assim...

Eles não se preocupavam com essa parte, eram mais culturalistas. Culturalistas nos dois sentidos: de se preocupar com o problema da cultura e de não atribuir à cultura fatores de ordem material, e assim por diante. Agora, o meu contato com o [Charles] Wagley foi decisivo, me orientou numa direção nova e muito mais avançada na antropologia.

\section{"Meu contato com o Wagley foi decisivo, me orientou numa direção nova e muito mais avançada na antropologia."}

Por que o senhor passou a se preocupar com a relação entre saúde e alimentação? Havia um motivo sociológico, algumas causas que fugissem ao ciclo da pura doença? Naquele tempo, apareceu o interesse pela questão alimentar e então entrei nisso, escrevi várias coisas. Não havia qualquer motivação particular. Josué de Castro chamava muito a atenção para os aspectos científicos da nutrição, tinha aquela revista de nutrição dele, e então acompanhei de perto seu curso...

Como Josué de Castro o influenciou em sua formação?

Fiquei um pouco mais ligado; foi nessa altura que imaginei a possibilidade de criar na Bahia uma faculdade de filosofia, a Faculdade Católica de Filosofia, mas me dirigi no sentido do serviço social, já que eu conhecia o pessoal lá em São Paulo.

O senbor fala, primeiro, de uma proposta de se criar uma Faculdade de Filosofia, depois segue para o servico social... por que razão o serviço social? A época em que o serviço social foi incorporado pela Universidade Católica do Rio de Janeiro é mais ou menos a mesma em que o serviço social foi incorporado pela Católica aqui de Salvador. Eu já trabalhava em alguma coisa na área de filosofia, relacionada com o catolicismo. Umas senhoras religiosas belgas, dedicadas ao serviço social, tinham uma escola em São Paulo. Elas iniciaram o movimento do serviço social e eu me relacionei muito com elas, fui para lá. Daí a influência de criar, na Bahia, alguma coisa nesse sentido. Mas aqui foi muito posterior.

Isso foi no final dos anos 30 ?

Mais ou menos... [1942].

A preocupação era oferecer formação religiosa, católica, em nível universitário, e o serviço social seria o embrião desse trabalbo?

Exato, está certo! Fui sempre muito motivado pelo catolicismo.

No Departamento de Saúde, o senbor trabalbou muito com essa parte de nutrição. Em geral, o trabalho nessa parte era mais constatar a desnutrição ou um estudo sobre a alimentação mais adequada à populaçâo?

Era muito isso e, também, inicialmente, não sei por que escrevi um trabalho, 'O vegetal como alimento e medicina do índio'. Não sei bem por quê, naquele período eu estava chegando para a antropologia. 
Quando foi sua aproximação com a antropologia? Esse artigo parece que é do inicio dos anos 40 .

Minha aproximação com a antropologia foi em 1942-43.

Aí de maneira mais formal, não é?

Mais formal, mais direta. Interessei-me por uma coleção lítica de um médico baiano, o dr. Vital Rego. Eram peças líticas, de pedras. Eu me interessei, achei uma curiosidade esse médico ter colecionado, aqui do rio São Francisco, umas trinta peças de pedra indígenas, não era material antiqüíssimo, não, mas coisas encontradas no rio; achei curioso e escrevi um artigo na Tarde sobre isto.

Por que o dr. Isaías Alves o convidou para ensinar antropologia na Faculdade de Filosofia em 1942?

Para mim é um mistério até hoje; existe um manuscrito dele com o nome de pessoas que ele convidaria a ensinar na faculdade, e lá está meu nome, mas não sei a fundamentação dele.

E por que aceitou ser professor de antropologia?

Era uma promoção pessoal para mim ensinar na faculdade e eu tinha certa curiosidade pelo tema.

Isso foi em 1942, antes bouve um contato com alguns antropólogos, sociólogos americanos aqui na Bahia. O senhor se lembra dessa experiência com intelectuais sociólogos?

Donald Pierson, Roger Bastide, porque a vinda de Wagley foi em 1950-51. O livro de Pierson, Negros e brancos no Brasil, me interessou muito, achei o tema muito curioso. Agora fiquei muito satisfeito em saber que ele está vivo e forte.

O senhor não se lembra quando ele esteve aqui na pesquisa de campo, tem essa lembrança?

Não, ele escreveu, referiu-se a um colega meu de turma, o Hosaná Oliveira, que teria colaborado com ele e tal, mas nessa ocasião eu não o conhecia pessoalmente.

$A$ análise de Donald Pierson sobre as relaçôes entre brancos e negros no Brasil realça um aspecto singular: o de que aqui bá reduzida influência do preconceito racial.

Ele dizia que o Brasil é um país multirracial, não acentuava antagonismos...

O senhor corroborava essa posiçâo do Donald Pierson?

Mais ou menos, porque sempre me parecia que aqui havia uma situação de convívio inter-racial tranqüila, sem hostilidades. Foi a razão pela qual Arthur Ramos indicou a Bahia para um dos estudos daquele programa que se fez aqui, no Recife e em São Paulo e no Rio de Janeiro também, com Costa Pinto.

Quando o senhor começou a dar aulas de antropologia na Faculdade de Filsofoia da Babia, lá ainda nâo havia universidade. O senhor era um curioso, e a partir daí como lidou com essa nova matéria?

Não sei por que o Isaías me chamou para isso, e comecei a ler a respeito. Me lembro que uma das primeiras coisas que li foi a Enciclopédia Britânica, depois a enciclopédia 
Social Sciences. Durante o curso secundário me habilitei a ler inglês, francês, o que me favoreceu muito; foi decisivo para mim.

A influência americana foi preponderante na sua formação em antropologia? Sim, depois, sobretudo, com a vinda de Wagley para a Bahia.

$A$ antropologia que o senbor ministrava nos primeiros tempos, a partir de 1942, tinha mais influência de antropologia fisica ou cultural?

Era mais antropogênese. Eu era muito preocupado com a formação do homem e a antropologia física, antropometria, tanto que tenho um trabalho com o dr. Galeão Santos sobre tipos físicos de escolares, peso e estatura, coisas assim, foi um dos meus primeiros trabalhos em antropologia.

Qual o objetivo desse trabalho de antropometria? Qual a intenção de se fazer um trabalbo como esse?

A intenção era mostrar as diferenças entre tipos baianos de diversas etnias.

Havia uma forte tradição da antropologia física de não só medir corpos, crânios, estruturas, mas derivar uma série de...

Índice encefálico era muito importante, tinha relação com graus de inteligência e coisas assim.

Em seu trabalho havia algum tipo de formulação tentando verificar a relação entre essas medidas e o potencial intelectual do indivíduo? Esse determinismo biológico era tão presente...

Não tinha uma motivação direta; era somente para verificar o que havia entre nós.

Esse tipo de estudo era muito freqüente no Rio de Janeiro na parte escolar; Arthur Ramos desenvolveu muitos trabalhos, não é?

Froes da Fonseca... Anísio ajudou muito o Arthur Ramos, quando ele criou a Universidade do Rio de Janeiro. Ele o atraiu, tanto que Arthur Ramos foi professor de antropologia, lá.

Gilberto Freyre também, não é?

Gilberto, não, diretamente... ele sempre viveu no Recife, mas Arthụ Ramos morava no Rio de Janeiro, e Anísio o atraiu.

Esse projeto da Universidade do Distrito Federal foi muito interessante, o senbor tem lembranças dele? Eles trouxeram muitos professores estrangeiros...

Anísio contratou Afrânio Peixoto para ir à Europa recrutar professores. Não sei se foi para isto, mas, indo à Europa, foi encarregado por Anísio de recrutar professores.

Qual é a sua análise da figura de Afrânio Peixoto?

Afrânio era um homem muito versátil, um talento: romancista e higienista, legista, médico no sentido geral, e muito simpático pessoalmente. Baiano, aqui do interior, criado em Belmonte e Pilar, essa zona de Porto Seguro. 
O senhor começou por essa parte de antropogênese, e ficou muito tempo trabalhando nessa linha?

Mais ou menos, os meus primeiros dois anos devem ter sido muito marcados, porque era aquilo em que eu era mais apto como médico, tinha estudado anatomia, fisiologia.

Ao mesmo tempo continuava com a sua atividade de médico, sendo professor de antropologia na faculdade?

É, médico do Departamento de Saúde, trabalhando em postos de saúde, por laboratórios de saúde. Fiz muita autópsia de rato para diagnóstico de peste bubônica, exames de laboratório de água para o Instituto Oswaldo Cruz.

\section{"Fiz muita autópsia de rato para diagnóstico de peste bubônica, exames de laboratório de água para o Instituto Oswaldo Cruz."}

Nesse periodo, de 1943 até final dos anos 40, o senhor continuou a trabalhar como professor ou já fazia pesquisas também?

Sempre fiz pequenas pesquisas com os alunos. Em 1953, Anísio Teixeira me encarregou de uma sobre freqüência escolar em uma determinada escola, e isso está na Revista Brasileira de Estudos Educacionais.

Queria que o senhor falasse sobre o periodo em que entrou para o ensino de antropologia, a época da criação da Faculdade de Filosofia, em 1943. Logo depoiso senhor fez Gaúchos.

Fui ao Rio Grande do Sul, em 1940, e fiquei encantado e surpreendido com o Rio Grande, inclusive com a presença do elemento imigrante europeu recente. Isso determinou que eu viesse mais tarde a escrever alguma coisa a respeito, sobretudo a respeito dos italianos. Inicialmente eu me impressionei com a presença alemã e é isso que consta do livro Gaúchos. Mais tarde, tendo ocasião de voltar a Caxias do Sul, dei atenção aos italianos.

Isso jä foi nos anos 60, não?

Anos $50 . .$. cinqüenta e tantos.

Esse trabalbo que o senhor desenvolveu já fazia parte daquela experiência de seminários de antropologia, que o senbor inaugurou na Faculdade de Filosofia, acha que tem alguma coisa com isso?

Conexão direta, não.

O que eram esses seminários, professor?

Aproveitar pessoas da Bahia e de fora que tinham relações com as ciências sociais, para darem alguma coisa aos alunos da Faculdade de Filosofia. 


\section{Qual a importância que atribui a esses seminários?}

Era uma variação da rotina das aulas: em vez de ficar somente dando preleções em sala de aula, aproveitava a presença de pessoas capazes de trazer alguma coisa diferente, nova, aos alunos.

Em geral, qual era a origem mais freqüente dos estrangeiros que vinham expor? Eram geógrafos, que naquele tempo havia aqui um certo movimento de geógrafos franceses, ou outra pessoa do terreno da assistência social que pudesse nos trazer qualquer tema.

\section{Relacionamento com Anisio Teixeira}

E o encontro do senbor com Anísio Teixeira, se dá na faculdade?

Não, o encontro com Anísio foi na Congregação Mariana Acadêmica Colégio Antônio Vieira.

Vocês eram colegas de estudo?

Não, ele era mais adiantado do que eu, tinha mais idade do que eu.

Nessa memória que o senbor escreveu, dá muito destaque à figura de Anísio Teixeira. Deram muito destaque ultimamente ao Anísio. Ele teve uma fase católica muito intensa. Quando foi aos Estados Unidos pela primeira vez, voltou com umas idéias diferentes em matéria espiritual. O que Isaías Alves recebeu do [John] Dewey como inspiração para o seu espiritualismo, Anísio traduziu como o oposto. Isaías revela, em trabalhos dele, que também ouviu muito o Dewey, mas não se deixou levar na direção que Anísio foi. De modo que, quando ele voltou a primeira vez dos Estados Unidos, o padre Luiz Gonzaga Cabral conversou muito com ele e ainda modificou suas idéias.

Entre os anos 20 e 30 acompanhava a situação do Rio de Janeiro e, especificamente, a atuação do seu amigo Anísio Teixeira, como secretário de Educação do governo Pedro Ernesto, certo?

Nessa ocasião fui ao Rio, e estive no gabinete de Anísio, onde encontrei várias pessoas da Bahia, e fiz um comentário a respeito disso. Depois soube que ele se queixou a uma tia minha, que morava no Rio, do comentário que fiz sobre uma das pessoas da Bahia a que ele dava apoio no Rio de Janeiro.

Que pessoas eram essas, naquela época, que já estariam no Rio de Janeiro? Lembra das pessoas que fariam parte desse grupo baiano?

Gente do campo da educação que se transferira para o Rio; uns trabalhavam com ele, outros ele ajudou, favoreceu, no tempo do governo Pedro Ernesto. Uma era Dulce Tude, sobrinha do Plínio Tude, meu padrinho, outra era minha tia, Izabel Goes Bezerra, e também havia uns rapazes... dois irmãos de muito valor que ele ajudou muito. Outros baianos já estavam também no Rio de Janeiro, como Arthur Ramos, Jerônimo Sodré Viana, Jesolvi, que era muito bom poeta, de esquerda, e tem um livro interessantíssimo chamado Caderno de Xangô, derivado de um período em que esteve 
refugiado por motivos políticos na casa de uma mãe-de-santo. Ele colheu dela receitas de comidas africanas e coisas assim.

Ele era comunista ou esquerda em geral, lembra se ele tinha filiação específica?

Era tido como comunista, talvez fosse, Anísio favorecia qualquer pessoa que parecesse a ele merecer, tanto de direita como de esquerda. Anísio foi acusado de comunista, mas ninguém era mais americanista do que ele, um grande admirador da América do Norte. O apelido de comunista veio muito da luta dele com a Igreja, aquela suspeição de que certas coisas fossem ativadas por comunista, mas não era!

Quando fala que Anísio era um grande admirador dos Estados Unidos, em que sentido, quais os elementos, o que mais realçava o Anisio em relação aos Estados Unidos?

Ele falava muito no regime político americano de liberdade, achava uma bobagem a gente se envergonhar de falar em dinheiro, dizia não haver motivo para a pessoa se envergonhar de falar em dinheiro e outras demonstrações, a lembrança dele do John Dewey...

Todo o processo educacional, não é?

$\mathrm{E}$ as idas dele aos Estados Unidos, pelo menos duas vezes... Anísio foi muito injustiçado. Em certa medida, teve o problema com Alceu Amoroso Lima por causa do abandono da religião católica. Ele era um católico de Congregação Mariana, veio da América mudado, sobretudo numa segunda viagem à América. Então aquilo repercutiu. Ele era um homem de muita sensibilidade, perdeu um filho num desastre no Rio de Janeiro. O filho dele foi encontrado morto ali no Flamengo, longe do automóvel em que vinha. Tinha ido à casa da noiva levar uns discos para ouvir, eu não sei se ele bateu contra outro carro ou contra uma árvore e morreu. Então Anísio me disse: "Nunca se é o mesmo depois de uma coisa dessa." Eu tive um relacionamento muito próximo com Anísio, um relacionamento pessoal independente de emprego, de atividade educacional, depois fui companheiro dele aqui, em 1951, quando ele criou a Fundação para o Desenvolvimento da Ciência na Bahia, no governo [Otávio] Mangabeira. Ele me fez secretário da fundação, de que depois fui presidente, e aí convivemos muito proximamente.

Fale-me da trajetória de Anisio Teixeira: ele sai da Secretaria de Educação do Distrito Federal, com o Pedro Ernesto, depois vem o Estado Novo. Ele volta para a Babia nesse periodo?

Não, Anísio foi para a Unesco, se não me engano.

Mas ai jâ no final dos anos 50, não é? Estou me referindo à época do Estado Novo, quando ele sai da prefeitura...

Lá por 1942, o Anísio veio para a Bahia. Houve um período em que ele estava no ostracismo político, dedicado ao comércio; Anísio ia para o porto ver embarque de manganês e coisas assim.

Ele foi contratado por alguma firma ou era coisa familiar?

Era uma firma com o irmão dele... era uma firma ligada mais à família dele. Importavam locomotivas. 
Quando o senhor fala em ostracismo deve ter a ver com esse periodo do Estado Novo, não? Porque ele saiu da prefeitura, foi mais ou menos expulso, na época do Estado Novo, deve ser nesse periodo.

Ah, é, ele andou muito pelo sertão, mas andou muito nos negóciọs aqui na Bahia. Exportando e importando, me lembro bem, importando locomotivas e exportando manganês; ele ia para o cais assistir aos embarques... Anísio era uma pessoa muito adaptável, facilmente adaptável.

Depois, com o governo Otävio Mangabeira, ele volta...

Mangabeira tirou Anísio da Unesco... Anísio estava por lá, quando Mangabeira o chamou.

O Otávio Mangabeira traz o Anísio e o que acontece? É mais ou menos desse periodo, 1950, o projeto Columbia University - Estado da Babia?

Bom, aí esse projeto é criado por Anísio, fruto do governo Otávio Mangabeira.

Há uma colocação anterior ao convênio, de que já havia alguns estudos econômicosociais na Babia, dos quais surgiu esse projeto.

Mas esses estudos não tinham nada com Anísio; ele imaginou entre 1949 e 1950 uma grande pesquisa social na Bahia, convidou Pierson, mas Pierson já estava comprometido com um projeto de pesquisa no vale do rio São Francisco.

\section{Convênio Columbia University — Estado da Bahia}

Gostaria que o senhor dissesse o que tem de informações, lembranças, sobre esse projeto Columbia University - Estado da Bahia, e o da Unesco...

Anísio queria um projeto que desse base para a orientação na educação, na administração, de um modo geral, no governo.

Qual era a sua intenção? Obter um perfil social da população para estabelecer politicas? Quem definiu a metodologia do trabalbo, as áreas?

Essa pesquisa seria um dado para ele, assim como o material de Pierson e assim por diante. Quando Anísio convidou o Wagley, ele era professor de Eduardo Galvão, do Museu Goeldi. Galvão estava fazendo doutoramento nos Estados Unidos com o Wagley, na Columbia. Eles conversaram em Nova York sobre o Brasil, o Wagley já conhecia o Brasil.

A experiência de Wagley na Amazônia é anterior a esse projeto?

É... Esse negócio da Amazônia foi a campanha da borracha. Parece que a fundação SESP [Serviço Especial de Saúde Pública] esteve envolvida com isso também.

Anisio também entrou em contato com o Eduardo Galvão para sondar a possibilidade da participação de Wagley?

Galvão era interessado nos índios da Amazônia, coisas assim... depois, quando Wagley chegou à Bahia, ele teve contato com Nestor Duarte, propiciado por Anísio. 
O que Nestor Duarte fazia nessa época? Tinha algum cargo?

Nestor Duarte era político muito ativo, muito inteligente, muito vivo nos apartes que dava e era casado com a irmã da mulher de Anísio.

\section{Estudos de comunidade}

Qual é o perfil da pesquisa desse convênio? Havia muita influência dos estudos americanos, estudos de comunidade, não é? Quais eram os autores que na época tinham maior influência teórica?

Que eu me lembre, um autor americano de 'estudos de comunidade' era Karl Withers. Ele escreveu Plainville, ou cidade comum, um estudo de uma típica comunidade americana. Ele era muito amigo de Wagley, padrinho de um de seus filhos.

A definição do projeto, da metodologia foi feita pelos americanos?

Um pouco pelo Galvão, e depois por pessoas com quem Wagley conversou... eu escrevi um trabalho sobre áreas culturais da Bahia e aquele trabalho sobre o próprio plano de pesquisa, sobre a vida social na Bahia, ou algo assim, com o Wagley e o Costa Pinto, que se afastou logo.

Fale um pouco da presença de Costa Pinto; foi chamado por quem?

Ele foi chamado por Anísio, porque o pai dele era daqui da Bahia. Era professor de higiene na Faculdade de Medicina da Bahia, foi diretor da Imprensa Oficial.

Ele já era da Universidade do Brasil nessa época, não?

Ele tinha um trabalho, de 1945, muito bom, Lutas de familia. Costa Pinto fez uma grande excursão pelo Recôncavo, levou uns dois meses numa caminhonete da secretaria percorrendo o interior.

\section{E o projeto Columbia?}

Foi confiado a mim e a Wagley, mas ele nunca assinou nenhum cheque, nem coisa nenhuma, quem mexia com tudo isso e sabe alguma coisa é Josildeth [Gomes Consorte] e ela tem o livro da escrita contábil da pesquisa. Eu tinha esse livro e dei a ela... Josildeth trabalhou aqui conosco, tinha sido aluna minha e Wagley gostou muito dela e do trabalho dela. Ele conseguiu para ela uma bolsa e ela foi fazer o doutoramento lá em Columbia. Lá ela ficou até ser chamada pelo governo do estado como professora.

O que me chama a atenção no projeto Columbia University - Estado da Bahia é que as áreas escolbidas são as que estavam fora de Salvador, eram áreas rurais. Fico imaginando o seguinte: tanto a Bahia como o Brasil em geral já começavam a se constituir como zonas cada vez mais urbanas. Ao mesmo tempo, há um grande projeto que vai estudar o rural...

Era o rural em relação com o urbano, porque o urbano é que coordenava o rural.

Como assim? O urbano coordenava o mural em que sentido?

Todo rural era governado pelo urbano, pela capital... a zona rural no Brasil nunca foi autônoma no sentido de se dirigir propriamente, ela sempre dependeu de orientação, 
direção... governadores aqui na Bahia, por exemplo, são sensivelmente mais preocupados e ocupados com os problemas da capital.

De certa maneira tem a ver com a escolba: antes eram cinco áreas que seriam trabalhadas, mas depois foram reduzidas para três... e o critério, por uma questão técnica e de aporte teórico, é de que seriam regiōes próximas a Salvador.

Sim, próximas pela facilidade de comunicações e pelo conhecimento que Salvador tinha dessas regiões, porque as áreas mais afastadas eram muito pouco conhecidas por aqui, mas o Nordeste, o Recôncavo estavam mais ligados à capital.

Queria que o senbor falasse um pouco sobre esse critério estabelecido de escolber uma comunidade tradicional e outra comunidade progressista... são termos utilizados no documento. Por que fazer esse tipo de comparação, de onde vem essa definição de comunidade tradicional e comunidade progressista?

Isso foi uma sugestão de Wagley a Anísio: comparar como é, por que houve mudança de atrasada para adiantada, e vice-versa.

Mas qual era o objetivo...

A antropologia estava muito preocupada com a mudança social. Anísio era uma pessoa progressista, então queria trazer algum elemento que contribuísse para que esse progresso se fizesse na direção realmente do novo, do adiantamento.

O que seria exatamente quando diz "O Anisio era progressista"? O que significa isso? Ele queria modernizar as instituições, atualizar os métodos de ação... é nesse sentido que falei em progressista. Ele era um homem contrário à rotina tradicional.

Os mesmos que participaram do projeto da Columbia participam desse volume organizado pelo Charles Wagley, Race and class in rural Brazil, não é?

É, Bill Hutchinson, Marvin Harris e Ben Zimmerman.

O que me chamou a atenção é que não estava contemplada a questâo racial no projeto que o senhor escreveu com Charles Wagley e Costa Pinto...

Não, só quando [Alfred] Metraux chegou aqui, que essa questão começou a ser tratada.

De certa maneira, o projeto Columbia facilitou a realização desses estudos sobre relações raciais, não é?

Acho que Metraux aproveitou a presença de uma equipe como aquela para tratar do assunto, porque ele se entendeu com Florestan [Fernandes], com [Roger] Bastide, lá em São Paulo, com René Ribeiro, em Pernambuco, e então aproveitou a Bahia.

Curioso é que o Costa Pinto, a princípio, ia trabalhar na Babia no projeto Columbia University - Estado da Babia e ele esteve aqui muito rapidamente. Parece que a contribuição dele foi muito pequena, não é?

Foi muito pequena. A contribuição dele está num artigo da revista do centro que Manoel Diegues dirigia, o Centro Latino Americano de Ciências Sociais. 
O projeto Columbia University - Estado da Bahia conseguiu realizar esse tipo de comparação entre região tradicional e progressista?

Sobretudo nos trabalhos de Marvin Harris pode-se encontrar um pouco sobre isto; este foi o único trabalho que, mais diretamente, resultou desse propósito.

Havia contato entre os trabalhos desenvolvidos aqui na Babia e os realizados em São Paulo?

Não, nenhum contato, eram completamente distintos.

Qual foi o trabalho específico do senhor no convênio Columbia University - Estado da Babia?

Tive um trabalho mais administrativo.

Teve representação acadêmica da Bahia no projeto? O que quer dizer com 'administrativo', o que seria isso?

Eu visitei algumas das comunidades, o dinheiro que se pagava aos pesquisadores passava por mim, coisas assim. Fui a Minas do Rio de Contas, a Monte Santo, ao Recôncavo, com Bill.

Quando ia a essas comunidades tinha alguma preocupação no sentido de explicar para as comunidades o tipo de trabalbo que estava sendo desenvolvido?

Não, só tive um trabalho dessa natureza, uma pesquisa de Anthony Leeds em Uruçuca. Houve uma dificuldade com ele e eu tive que ir lá explicar ao promotor, ao juiz, ao vigário, o que estava se fazendo. Leeds queria saber quantas roupas a pessoa possuía, quantos sapatos e coisa e tal, então ficaram desconfiando dele, uma coisa contraditória, de comunista e de imperialista americano.

Depois, Anthony Leeds veio a fazer um trabalho muito importante sobre a questão urbana no Brasil, em favelas...

Ele trabalhou com favelas aqui e no Peru, se não me engano. O livro dele tem prefácio meu, chama-se A sociologia do Brasil urbano (1968).

\section{Fundação de apoio ao desenvolvimento científico}

Queria que o senhor falasse um pouco da fundação de uma instituição estatal de fomento.

Em 1950, o Anísio teve a idéia de criar a Fundação para o Desenvolvimento da Ciência na Bahia, que atuou durante vários anos. Seu objetivo era dar embasamento científico ao desenvolvimento do estado.

Essa fundação atuava em várias áreas, quais?

Ela manteve esse programa da Columbia com o estado da Bahia. Anísio convidou Paulo Carneiro, líder positivista que manteve a casa de Augusto Comte em Paris durante muito tempo, para dar um início ideológico, uma coisa assim. De modo que a fundação começou a funcionar com esta palestra do Paulo Carneiro. Fui o primeiro secretário da fundação. 


\section{O governo da Bahia canalizou recursos para essa fundação?}

Bom, logo que Anísio instituiu o programa, uma coisa objetiva em que ele podia aplicar esses recursos era o convênio com a Columbia. Era uma quantia considerável, mas nada fora do comum, tanto que não chamou muita atenção, nem houve contestação.

Qual foi a divisão, em termos de recursos, entre a Columbia University e o estado da Bahia? A Columbia também deu dinheiro para esse projeto?

Só deu o nome e as pessoas. Em julho de 1950, chegaram aqui três rapazes americanos, doutorandos de antropologia da Columbia, com Wagley, depois veio Anthony Leeds. Os três rapazes eram Ben Zimmerman, William Harry Hutchinson, o Bill, e Marvin Harris.

\section{"Em 1950 chegaram três rapazes americanos, doutorandos de antropologia da Columbia... Ben Zimmerman, William Harry Hutchinson e Marvin Harris."}

E quando mesmo foi criada a Fundação para o Desenvolvimento da Ciência na Babia? Em 1951, quando o Anísio Teixeira era secretário de Educação na Bahia e resolveu criá-la.

Quais eram os objetivos da fundação?

A resolução de problemas em bases científicas. Dar sentido científico exato às informações recolhidas.

Quais eram as atividades da fundação?

Além do convênio entre o governo do estado da Bahia e a Columbia University, que era o principal, procurava-se recolher material sobre outros elementos, outros dados, também do ponto de vista científico, rigoroso, para que não se ficasse na simples conjectura.

A fundaçâo seria um órgão de amparo à pesquisa, como se diz boje em dia.

De amparo à pesquisa, sobretudo no terreno social.

No primeiro momento, o senhor não estava vinculado em termos acadêmicos ao projeto Columbia University - Estado da Bahia, tinh a um papel mais administrativo e de auxilio aos pesquisadores americanos que estavam aqui. Depois tornou-se também um dos pesquisadores. Não é isso?

Exatamente.

O senhor já tinha interesse sobre relações raciais antes do projeto Unesco? Muito vagamente. Eu tinha escrito um artigo sobre o assunto. Aí veio esse relacionamento.

Há alguns trabalhos seus, como 'Civilização e mestiçagem', um outro sobre antropologia física, nesse campo. Acredita que foi a partir dai que bouve interesse em sua participaçâo no projeto? Charles Wagley teve papel importante na sua indicação? 
Acho que sim. Wagley era considerado uma pessoa de muito valor e de bom relacionamento com o Brasil, de maneira que ele teve um papel relevante nesse particular.

Gostaria que o senhor falasse da experiência da vinda de Alfred Metraux à Babia.

Ele ficou na Fundação para o Desenvolvimento da Ciência; esteve hospedado lá duas vezes. Fez uma viagem ao nordeste do estado, e encontrou população que ele supôs tivesse uma língua antiga, e estivesse esquecida ali. Escreveu a esse respeito naquela revista da Unesco, e depois verificou que foi um engano da parte dele. Ele veio à Bahia, não posso recordar bem em que condições, mas sempre ligado a Anísio Teixeira.

Por que razão escolbeu trabalbar com as elites de cor, e não com os negros em geral? Eu era a pessoa que, na Bahia, se ocupava desses assuntos. Não havia razão particular. Mas trabalhei nisso amplamente.

Percebeu nas elites de cor, na Babia, alguma diferença para com a elite branca ou os brancos em geral?

Só relendo... acho que não... prevenção era contra o mulato; mulato foi sempre considerado um estranho. Não era branco nem preto, pernóstico, inteligente, porém desajustado, menos adaptado ao meio.

\section{“... prevenção era contra o mulato; mulato foi sempre considerado um estranho."}

\section{Essa era a imagem ou a situação?}

Era a imagem comum do mulato.

O senhor escolheu sua filha, d. Sylvia [David de Azevedo], e d. Josildeth [Gomes Consorte] como suas auxiliares de pesquisa. Quais foram os motivos da escolba dessas pessoas? Elas trabalhavam mais diretamente comigo.

Qual é a formação de d. Sylvia? E qual é a origem e a trajetória da profa. Josildeth? Sylvia é assistente social. Josildeth se encaminhou na antropologia. Ela foi aluna da Faculdade de Filosofia e se interessou pelo trabalho que eu fazia. E como vi que ela era uma pessoa capaz, a atraí para esse campo; não tinha outra razão. Depois ela foi trabalhar no Rio de Janeiro com o Anísio Teixeira, no Centro Brasileiro de Pesquisas Educacionais, por indicação minha.

\section{Produção intelectual}

Antes do projeto Columbia University - Estado da Babia, o senhor já tinha feito um trabalbo sobre Salvador, um grande levantamento, não foi isso?

Para as comemorações dos quatrocentos anos de fundação da cidade de Salvador pelo governo [Otávio] Mangabeira, em 1949, fui encarregado de escrever alguma coisa 
sobre o povoamento da cidade e aí fiz esse trabalho. Levei muito tempo trabalhando nisso, tanto que minha senhora dizia que eu estava sem coragem de escrever... eu não estava sem coragem, estava sem saber como começar um trabalho dessa natureza.

Por quê?? Explique-me melhor isso. Fez um levantamento exaustivo?

Levei uns quatro, seis anos incumbido desse trabalho sobre povoamento. O quarto centenário de Salvador deu lugar a uma série de trabalhos: o meu, de Luís Viana Filho, Afonso Rui, de várias outras pessoas. A mim coube um título já definido: 'Povoamento da cidade de Salvador', e custei a acertar como entrar no assunto, na hora de escrever. Levei anos colhendo material, e a partir dele escrevi aquele trabalho.

\section{"O quarto centenário de Salvador deu lugar a uma série de trabalhos: o meu, de Luis Viana Filho, Afonso Rui."}

Era um trabalho que ia até a época contemporânea.

Ia até 1949.

Ele traçava o quê? Abordava os aspectos econômicos, sociais, politicos?

Todos, de vários autores, cada um com um assunto. Luís Viana Filho, Afonso Rui, e assim por diante.

Havia a intenção de apresentar subsídios para um processo de desenvolvimento na Babia? A intenção era essa?

Da parte de Mangabeira, era!

E o que era desenvolver a Bahia?

A Bahia estava num período de estagnação econômica... muitos anos desde que o comércio da cana-de-açúcar caiu... a Bahia perdeu o seu maior apoio econômico e então entrou numa fase de estagnação.

O que representou Otávio Mangabeira nesse período, em termos de inovação?

Ah, o Otávio Mangabeira foi um governante muito integrado à Bahia, queria fazer alguma coisa nova; criou uma organização de estudos econômicos na Bahia, em que trabalharam Rômulo Almeida [economistal, Nestor Duarte [político e intelectual, casado com a irmã da mulher de Anísio] e Milton Santos [geógrafo].

Queria que o senhor falasse das suas relações com Gilberto Freyre, jâ que ele, em 1943, prefacia Gaúchos, não é?

Eu aproveitei um texto dele no Correio da Manhâ, ele não prefaciou o livro. Não me lembro como foi o primeiro contato com Gilberto, mas ele me convidou muito mais tarde para uma reunião lá em Fazenda Nova, interior de Pernambuco, depois para outra reunião em Garanhuns, e, finalmente, no próprio Recife.

E essas reuniões tinham que objetivo?

Eram sobre temas da antropologia brasileira, particularmente do Nordeste. 
Foi depois de Gaúchos ter sido publicado, não é?

Depois de 1943, porque li Casa-grande e senzala e fiquei muito interessado, não sei se escrevi a ele, não me lembro como foi essa aproximação.

O que achou do livro?

O livro chama muita atenção porque ele se ocupava de coisas muito novas, a escravatura, relações entre senhor e escravo.

Esse trabalbo teve influência sobre as suas reflexões?

Ah, teve, sobre toda a antropologia brasileira, particularmente relativa ao Nordeste, o trabalho do Gilberto era muito original na abordagem que ele fazia dos temas.

Quais aspectos destacaria em termos de originalidade do trabalbo dele?

Do relacionamento do senhor com o escravo, me parece que foi patriarcado brasileiro, classes sociais etc.

No projeto Unesco, é interessante notar que o trabalho de Charles Wagley sobre raçase classes abrange sobretudo o ambiente rural. O trabalho do senbor é totalmente distinto, não? O senbor desenvolveu o trabalbo em Salvador.

Salvador, as elites de cor. Trabalhei com Josildeth e Sylvia, a minha filha, inclusive com pontos de vista diferentes. Por exemplo, no Clube Baiano de Tênis tinha uma coleção de fotografias dos sócios. A classificação que elas faziam eram diferentes. Muitas pessoas que Silvia considerava mulatas Josildeth considerava brancas.

Há muitos trabalhos a partir de fotografias e esse tipo de discordância é até interessante, porque revela bem a questão da representação: uma fotografia é uma fotografia, não é uma coisa que simplesmente tirou e está ali, não é?

Naquela mesma ocasião, Marvin Harris trabalhou aqui com uma série de fotografias de cabeças de pessoas, utilizando diferenças de tipos raciais nas mesmas famílias, e também terminologias relacionadas com raças.

\section{"Marvin Harris trabalhou aqui com umá série de fotografias de cabeças de pessoas, utilizando diferenças de tipos raciais nas mesmas familias."}

Como definia as pessoas que ia entrevistar? Eu me lembro que o senhor faz a primeira amostra, depois faz uma seleção dessa amostra...

Eram pessoas que, no meu juízo, tinham reconhecimento no meio baiano e eram de cor.

O senhor tinha conhecimento sobre...

Sobretudo do grupo profissional e acadêmico.

Como eram essas entrevistas? Convidava uma pessoa para ser entrevistada e tomava notas?

Dizia o que tinha em vista, e tenho dois cadernos aí sobre isso. Ia lá conversar com as pessoas sobre os assuntos. 
O que o impressionava mais nessas entrevistas?

A boa vontade das pessoas em conversar sobre o assunto, aquilo me chamou muita atenção; não sei se era boa vontade comigo ou com o tema.

$E$ as perguntas mais delicadas, relacionadas à discriminação, ao preconceito? Quais as experiências que eles tinham de choques culturais e de choques raciais...

E o que observou em relação a essas respostas?

A maioria acentuava essa coisa que eu também defendo: não tiveram choques hostis.

O senhor mantém essa tese até hoje, no que diz respeito a essas relaçôes que se dão entre grupos raciais?

Na Bahia não há um conflito visível, facilmente perceptível, entre esses grupos. Meu ponto de vista é esse. [Pierre] Verger chama muito a atenção para isso; há muito poucos meses, Verger repetiu: em lugar nenhum ele encontrou compatibilização tão equilibrada entre tipos diferentes como na Bahia. Ele ficou inserido nos grupos de cor, em contato com a sociedade baiana em geral. Ele é muito querido no meio baiano em geral.

Muito interessante o senbor começar o seu trabalho com uma citação de Stefan Zweig, aquilo é muito significativo, como se o senbor, de certa maneira, corroborasse as impressões de Stefan Zweig...

Devia ser sobre esse relativo equilíbrio entre os tipos, possivelmente era isso, Zweig passou dias aqui na Bahia.

Esse seu trabalbo foi publicado pela Unesco e causou grande impacto. Qual a sua impressão sobre seu trabalbo, se comparado aos do pessoal de São Paulo? Florestan Fernandes conclui que, pelo menos em São Paulo, não ocorre essa barmonia.

Lá em São Paulo havia uma elite política de cor, digamos assim, que lutava por suas reivindicações, ao passo que aqui não havia.

O senhor menciona essa elite politica, a 'frente negra brasileira'...

É curioso que meu livro As elites de corfoi o mais vendido, esgotou. Não sei por quê, talvez tenha sido o pessoal de São Paulo querendo comparar São Paulo com a Bahia.

O senbor afirma: "O caso de São Paulo é diferente porque as elites de cor, lá, tinham uma organização política”...

É, Florestan [Fernandes] já era líder de uma luta entre o pessoal de,cor e os brancos, e aqui não.

O prof. Florestan já era um lider?

Por causa da orientação política dele, sempre acentuou um pouco esse caráter.

Ao eleger o Brasil como um exemplo que poderia ser seguido pela bumanidade, a Unesco tinha uma expectativa. E, no caso de São Paulo, o Florestan procura mostrar que houve uma certa frustração no modelo... o preconceito era uma coisa muito forte... E ele era um participante. 
O senhor teve contato com organizaçôes politicas negras em Salvador nessa época em que fez a pesquisa?

Fiz contatos com líderes negros.

Lideres negros muito mais culturais ou religiosos que políticos?

$\mathrm{Ah}$, políticos não eram, de uma maneira assim ostensiva.

Outro aspecto que me chama a atenção é que, no projeto Unesco, a equipe e mesmo as pesquisas foram mais amplas do que nos outros estados. No caso de Recife foi René Ribeiro. O senhor o conbeceu?

Muito. René foi encarregado de um determinado trabalho, 'A religião e as relações raciais', e, no nosso caso, aqui na Bahia e em São Paulo, foi mais aberto, amplo, menos centrado num tema determinado. Também fez um estágio lá na antropologia, com Herskovits, na Northwestern University, Chicago.

Ele tem um artigo de 1945 sobre relações raciais no Brasil, saiu na American Sociological Review, porém ele trabalhava mais na parte religiosa.

Sim, o tema que ele foi incumbido de desenvolver era esse, talvez porque lidasse com Xangô, já trabalhava lá no Recife, mais esse ponto de vista. Ele trabalhou sempre mais com psiquiatria e medicina.

Depois de ter feito esse trabalho sobre 'as elites de cor', continuou a escrever nessa área de relações raciais?

Publiquei Cultura e situação racial, estimulado por Otávio Ianni. Ele esteve na Bahia e conversou comigo, me estimulou e levou a efeito a publicação.

O senhor diz que na Bahia havia preconceito, mas que isso não impedia a mobilidade social dos negros.

De um negro individualmente. Enquanto grupo, era exatamente esse o problema, e é o problema até hoje!

Por que, então, essa contradição?

Não sei. Um dos problemas dessa questão é que eles podem progredir pessoalmente, apesar do condicionamento pelo tipo físico, etnia, mas como grupo não crescem, não melhoram, não avançam.

Acredita que ai entre a discriminação?

Acho que sim. A discriminação como fenômeno global, geral, fundamental.

Então, de certa maneira, isso converge com as posições do pessoal de São Paulo, porque acho que também há essa posição de considerar que, enquanto grupo, não consegue ascender..

Com uma diferença: em São Paulo e no Sul, no Rio Grande por exemplo, há os jornais negros, entre aspas, houve luta expressa em favor das reivindicações deles, ao passo que na Bahia isso não é tão evidente... Não sei por quê, o negro na Bahia ficou mais ligado à escravidão, menos alfabetizado, menos politizado, de maneira que esses elementos não contaram muito. 


\section{“...o negro na Bahia ficou mais ligado à escravidão, menos alfabetizado, menos politizado."}

Esse livro que o senhor escreveu teve grande repercussão: o senhor foi convidado a ir a Columbia, logo depois desse trabalbo, não?

Fui, em 1952. Foi uma simples visita a instituições universitárias americanas, não foi um trabalho propriamente. Esse convite veio em conseqüência do projeto da Columbia com o governo da Bahia.

Depois o senhor foi para outras universidades?

Visitei uma e outra, mas não parando, fazendo trabalho.

A única em que parou para ser professor foi Columbia?

Columbia, em 1971 e uma palestra na City University of New York.

Estranbou a sociedade americana?

Estranhei, mas também admirei certas coisas relativas à facilidade que me deram de receber dinheiro, viajei muito, e me admirei com a relativa falta de burocracia.

E suas aulas na Columbia University, sentia que havia muito interesse pelo Brasil?

Nunca atraí grande número de ouvintes ou alunos, eu não tinha notabilidade, quando se anunciava que eu ia falar sobre qualquer coisa, apareciam interessados, mas não em grande número.

Eram mais conferências ou cursos?

Eram mais aulas, para 15 , vinte alunos.

Em geral eram sobre que temas?

Brasil em geral ou notícias sobre o Brasil.

Os outros trabalbos que desenvolveu... aquele que foi publicado pela Vozes sobre democracia racial, de certa maneira, segue a mesma linba de trabalho que tinha feito antes para a Unesco. Ou acha que modificou alguma coisa do seu pensamento sobre relações raciais? Ao intitular um livro seu de Mito da democracia racial, o que estava criticando nesse mito?

Estava querendo mostrar que era um falso posicionamento, não havia realmente democracia racial. Falava-se em democracia racial, mas não era.

Essa sua posição se diferencia daquela de Gilberto Freyre quanto às relações raciais no Brasil? Não acha que haveria uma diferença onde diz que essa questão da democracia racial é falsa?

Não, digo que é falsa no sentido mais profundo, mas acho que segui as linhas do próprio Gilberto.

Gilberto Freyre, a partir de um certo momento, é muito criticado pela idéia de que as relações raciais no Brasil seriam paradisiacas. Essa é uma das críticas fortes que se faz a Casa-grande e senzala... 
Pode ter parecido isso até porque Gilberto foi julgado com base no posicionamento político. Ele foi um pouco esquerda, um período apoiado pelo pessoal de esquerda, mas depois mudou muito na direção oposta, então o julgamento dele estava muito condicionado a essas posturas.

Entende que há uma linha de coerência sua em relação aos outros trabalhos que produziu sobre relações raciais, cujo ponto de partida são as elites de cor?

Nunca quebrei essa linha, de uma maneira sensivel, ostensiva. Não, nunca quebrei, desde Civilização e mestiçagem, publicado aqui na Bahia pelo Manoel Pinto de Aguiar, pela Editora Progresso.

Uma referência forte do senhor é o trabalho do prof. Donald Pierson, certo? Negroes in Brazil, edição norte-americana, 1942, ou Brancos e pretos na Bahia, edição brasileira, 1945.]

Sim, porque era um trabalho muito científico, sociológico, sobre a Bahia. Exatamente sobre brancos e pretos na Bahia.

E o senhor acha que, de certa maneira, é mais um conjunto de dados que confirmam a tese do prof. Donald Pierson ou ele vai além?

Contribuem para a tese dele, no sentido da sociedade multirracial de classe.

Qual a importância desse seu envolvimento - tanto no projeto conjunto Columbia University e estado da Babia como depois, no projeto Unesco - para a sua carreira profissional? Como esses trabalhos contribuiram para o desenvolvimento da sua carreira profissional?

Nessa ocasião fui aos Estados Unidos, fiz contatos lá com várias pessoas, e isso mudou um pouco as minhas perspectivas, porém dizer objetivamente em que consistiu é mais difícil.

Parece que há dois marcos importantes na sua conversão à antropologia cultural e/ou social. Um seria a sua entrada para a recém-fundada Faculdade de Filosofia da Babia, em 1942. O outro marco seria a sua participação na parte executiva do projeto Columbia University - Estado da Bahia e na parte acadêmica do trabalbo da Unesco. Parece que esse segundo marco faz com que o senhor dê um salto na carreira, tornase uma referência. Sua bibliografia, apesar de bastante diversificada, tem a marca dos estudos étnicos muito forte a partir de As elites de cor.

O contato com Charles Wagley e o grupo da Columbia foi decisivo para a minha carreira; modificou-a muito, tornando muito mais objetiva a perspectiva dos problemas e o tratamento dessas questôes. Eu tinha idéias, um modo de pensar pessoais, mas sem embasamento objetivo e, a partir daí, comecei a ter uma visão mais concreta dos fatos.

Guerreiro Ramos foi uma pessoa extremamente polêmica e estabeleceu uma série de discussões; travou grande polêmica com o prof. Florestan Fernandes e mantinha uma certa rivalidade entre a sociologia feita no Rio de Janeiro e a feita em Sâo Paulo.

É, ele falava muito numa sociologia consular, importada.

No livro O processo da sociologia no Brasil ele falou na sociologia consular do litoral, a favor de uma sociologia euclidiana. Ele faz uma crítica ao senhor na Introdução 
crítica à sociologia brasileira, no sentido de que todos os trabalhos feitos até então viam o negro como material etnográfico, como peça de museu, e não como elemento ativo da sociedade. Ele tinha essa critica aos trabalhos desenvolvidos pela Unesco. O senhor também fez uma observação no sentido da diferença entre o trabalbo feito pelos pesquisadores da Bahia e os de São Paulo. Quais seriam as diferenças entre os trabalbos produzidos nesses dois lugares?

Os trabalhos da Bahia têm certa objetividade e tranqüilidade e os de São Paulo visavam muito as lutas que se desenvolviam entre esses elementos, de modo que tinha uma ênfase um pouco diferente. Bom, maior distinção é difícil fazer hoje.

\section{Ficha técnica}

Local: Salvador, Bahia

Data: 14 e 15 de abril de 1994 e

5 de julho de 1995

Duração: 8 horas

Entrevistador: Marcos Chor Maio

Texto introdutório: Josildeth Gomes Consorth

Leitura e cortes prévios: Nisia V. T. Lima, Paulo Gadelha

Conferência de fidelidade: Carlos Henrique Paiva

Edição: Ruth B. Martins

Revisão: M. Cristina Ramos Britto 